\title{
Long-range transport of giant particles in Asian dust identified by physical, mineralogical, and meteorological analysis
}

\author{
G. Y. Jeong ${ }^{1}$, J. Y. Kim ${ }^{2}$, J. Seo ${ }^{2,3}$, G. M. Kim ${ }^{1}$, H. C. Jin ${ }^{2}$, and Y. Chun ${ }^{4}$ \\ ${ }^{1}$ Department of Earth and Environmental Sciences, Andong National University, Andong 760-749, Republic of Korea \\ ${ }^{2}$ Korea Institute of Science and Technology (KIST), Seoul 136-791, Republic of Korea \\ ${ }^{3}$ School of Earth and Environmental Sciences, Seoul National University, Seoul 151-742, Republic of Korea \\ ${ }^{4}$ Asian Dust Research Division, National Institute of Meteorological Research, Seoul 156-720, Republic of Korea
}

Correspondence to: G. Y. Jeong (jearth@anu.ac.kr)

Received: 28 May 2013 - Published in Atmos. Chem. Phys. Discuss.: 13 August 2013

Revised: 8 November 2013 - Accepted: 3 December 2013 - Published: 15 January 2014

\begin{abstract}
Giant particles transported over long distances are generally of limited concern in atmospheric studies due to their low number concentrations in mineral dust and possible local origin. However, they can play an important role in regional circulation of earth materials due to their enormous volume concentration. Asian dust laden with giant particles was observed in Korea on 31 March 2012, after a migration of about $2000 \mathrm{~km}$ across the Yellow Sea from the Gobi Desert. Scanning electron microscopy (SEM) revealed that $20 \%$ of the particles exceeded $10 \mu \mathrm{m}$ in equivalent sphere diameter, with a maximum of $60 \mu \mathrm{m}$. The median diameter from the number distribution was $5.7 \mu \mathrm{m}$, which was larger than the diameters recorded of 2.5 and $2.9 \mu \mathrm{m}$ in Asian dust storms in 2010 and 2011, respectively, and was consistent with independent optical particle counter data. Giant particles $(>10 \mu \mathrm{m})$ contributed about $89 \%$ of the volume of the dust in the 2012 storm. Illite-smectite series clay minerals were the major mineral group followed by quartz, plagioclase, K-feldspar, and calcite. The total phyllosilicate content was $\sim 52 \%$. The direct long-range transport of giant particles was confirmed by calcite nanofibers closely associated with clays in a submicron scale identified by high-resolution SEM and transmission electron microscopy. Since giant particles consisted of clay agglomerates and clay-coated quartz, feldspars, and micas, the mineral composition varied little throughout the fine $(<5 \mu \mathrm{m})$, coarse $(5-10 \mu \mathrm{m})$, giant-S $(10$ $20 \mu \mathrm{m})$, and giant-L ( $>20 \mu \mathrm{m})$ size bins. Analysis of the synoptic conditions of the 2012 dust event and its migration indicated that the mid-tropospheric strong wind belt directly stretching to Korea induced rapid transport of the dust, deliv-
\end{abstract}

ering giant particles. Giant dust particles with high settling velocity would be the major input into the terrestrial and marine sedimentary and ecological systems of East Asia and the western Pacific. Analysis of ancient aeolian deposits in Korea suggested the common deposition of giant particles from Asian dust through the late Quaternary Period. The roles of giant particles should be reviewed with regard to regional circulation of mineral particles and nutrients.

\section{Introduction}

Asian dust is composed of soil particles from the surfaces of western China and Mongolia. Asian dust is transported eastward across China, Korea, Japan, and the North Pacific. The size, morphology, chemistry, and mineralogy of dust particles are important for modeling their transport (Westphal et al., 1987; In and Park, 2002), radiative impacts (Tegen and Lacis, 1996; Reid et al., 2003; Park et al., 2005; Kandler et al., 2007; Kim et al., 2008), and chemical reactions (Laskin et al., 2005; Jeong and Chun, 2006; Dentener et al., 1996; Sullivan et al., 2009; Song et al., 2013). They supply inorganic nutrients to marine ecosystems (Meskhidze et al., 2005), and are eventually deposited on land and the ocean floor to form aeolian sediments, recording paleoclimatic changes through the Quaternary Period (Bradley, 1999). The Korean Peninsula lies in the main path of the Asian dust transfer and is suitable for observation of its physical, optical, and chemical characteristics (Seinfeld et al., 2004). 
In studies of mineral dust, attention is often paid to fine particles because they are more respirable, produce harmful effects (Dockery et al., 1993), react with gaseous pollutants (Dentener et al., 1996), and reflect light close to solar wavelengths (Tegen and Lacis, 1996). Modeling of the radiative properties of mineral dust considers particles $<10 \mu \mathrm{m}$ because the atmospheric lifetime of particles $>10 \mu \mathrm{m}$ is less than 1 day (Tegen and Lacis, 1996; Seinfeld and Pandis, 2006). Chun et al. (2001) suggested that particles $>10 \mu \mathrm{m}$ in Asian dust collected in Korea may be derived from local sources. Thus, real-time monitoring networks of Asian dust by governmental institutes of Korea (National Institute of Environmental Research and Korea Meteorological Administration) measure $\mathrm{PM}_{2.5}$ and $\mathrm{PM}_{10}$, but not total suspended particulate (TSP) matter.

Although particles $>10 \mu \mathrm{m}$ have attracted little attention, they can be transported over long distances, and may play significant roles in regional circulation of materials. Longrange transport of coarse particles has been reported in Saharan dust across the Atlantic Ocean and the Mediterranean Sea (Goudie and Middleton, 2001; Díaz-Hernández and Párraga, 2008). However, there are rarely reports dedicated to the research of coarse mineral dusts providing systematic data of particle size and mineralogy with a meteorological interpretation about their outbreak and migration. Although number concentrations of relatively coarse particles are normally low compared with fine particles, their mass/volume concentrations can be high (Seinfeld and Pandis, 2006). The mass flux of dust via dry deposition can be controlled by a relatively small fraction of aerodynamically large particles (Coude-Gaussen et al., 1987; Arimoto et al., 1997). They are absorbers of light at thermal wavelengths (Tegen and Lacis, 1996). On a regional scale near dust sources, the radiative effect of coarser particles is not negligible (Ginoux, 2003). The bulk geochemistry and isotopic composition of dust have largely been determined for TSP, where the mass is dominated by coarse particles (Kanayama et al., 2002).

The modal particle diameters of volume-size distribution of Asian dust have been reported to range from 2 to $4 \mu \mathrm{m}$ as measured with an optical particle counter in Seoul, Korea (Chun et al., 2001, 2003; Jeong, 2008), and British Columbia, Canada (McKendry et al., 2008), and using a cascade impactor in Japan (Mori et al., 2003; Mikami et al., 2006). However, size distribution curves of Asian dust often extend over $10 \mu \mathrm{m}$. Park and Kim (2006) reported a mean diameter of $9.12 \mu \mathrm{m}$ on a mass basis using a cascade impactor in Seoul. In addition, there are probably interevent and inevent fluctuations of particle size distribution depending on synoptic conditions, which have not been studied in detail. Giant particles were observed in the central North Pacific by Betzer et al. (1988), who traced them to Asian sources, indicating global circulation of giant particles. However, there are almost no reports on the occurrence and characterization of Asian dust heavily laden with giant particles despite numerous articles on Asian dust events.
Asian dust was observed in Korea on 31 March 2012. Despite a low TSP concentration, it was laden with giant particles compared to two previous events (2010 and 2011). The 2012 dust provided a unique opportunity to observe the longrange transport of the giant particles. We report physical, mineralogical and meteorological characteristics of the 2012 dust event, in comparison to previous events, and discuss the remote origin of giant particles as well as the implications for regional circulation of mineral particles and elements. Here, dust particles were classified as fine $(<5 \mu \mathrm{m}$ in diameter), coarse $(5-10 \mu \mathrm{m})$, giant-S $(10-20 \mu \mathrm{m})$, and giant-L $(>20 \mu \mathrm{m})$ particles.

\section{Dust outbreak and migration}

In terms of spatiotemporal evolution of the dust storm, the infrared measurements by geostationary satellites are fairly useful to trace the dust outbreak and migration in the shortterm timescale. To detect dust aerosols from the satellite, the brightness temperature difference (BTD) between $10.8 \mu \mathrm{m}$ and $12.0 \mu \mathrm{m}$ bands $\left(T_{11 \mu \mathrm{m}}-T_{12 \mu \mathrm{m}}\right)$ has been widely used (Ackerman, 1997). BTD is positive over a thin ice cloud and negative over the dust storms (Chaboureau et al., 2007). However, since the BTD technique has low sensitivity on the ocean and discontinuity between daytime and nighttime images, other dust indices have been developed and provided by the Korea Meteorological Administration (KMA).

In this study, aerosol index derived from the Communication, Ocean, and Meteorological Satellite (COMS) of the KMA launched on 27 June 2010 is used for the dust events in 2011 and 2012 (Fig. 1). The COMS aerosol index is based on the BTD technique, but derived from the difference between BTD and the background threshold value (BTV), which is defined as a difference between the maximum of $T_{11 \mu \mathrm{m}}$ for the past 10 day and observed $T_{12 \mu \mathrm{m}}$ at each pixel. Since BTV and BTD are same in the clear sky condition, the difference between BTD and BTV can be utilized for the detection of the Asian dust (Hong et al., 2010). To reveal the 2010 dust event, which occurred before the launching of COMS, we also show (in Fig. 1) the infrared difference dust index (IDDI) (Legrand et al., 2001) derived from the Multi-functional Transport Satellite-1R (MTSAT-1R) of the Japan Meteorological Agency launched on 26 February 2005. MTSAT-1R IDDI is based on the brightness temperature in the dust-sensitive $10.8 \mu \mathrm{m}$ band $\left(T_{11 \mu \mathrm{m}}\right)$ and is derived from the difference between $T_{11 \mu \mathrm{m}}$ in the clear sky condition and observed $T_{11 \mu \mathrm{m}}$.

The images of COMS aerosol index during the 2012 dust event (National Meteorological Satellite Center, 2013) reveal the dust outbreak in the Gobi Desert of southern Mongolia and northern China $\left(40^{\circ}-45^{\circ} \mathrm{N}, 90^{\circ}-105^{\circ} \mathrm{E}\right)$ at around 12:00 Korea Standard Time (KST) on 30 March 2012 and its migration to the east (Fig. 1). The dust arrived at the western coast of Korea at around 16:00 KST on 31 March, based 


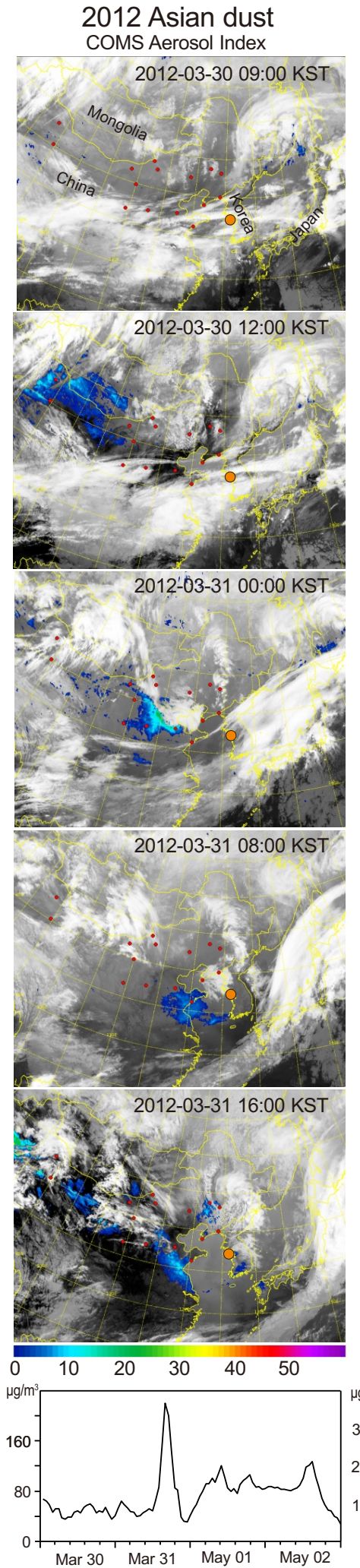

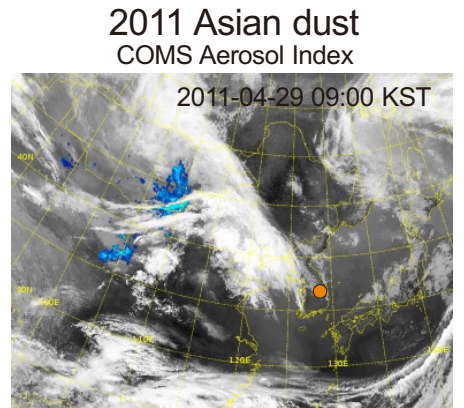
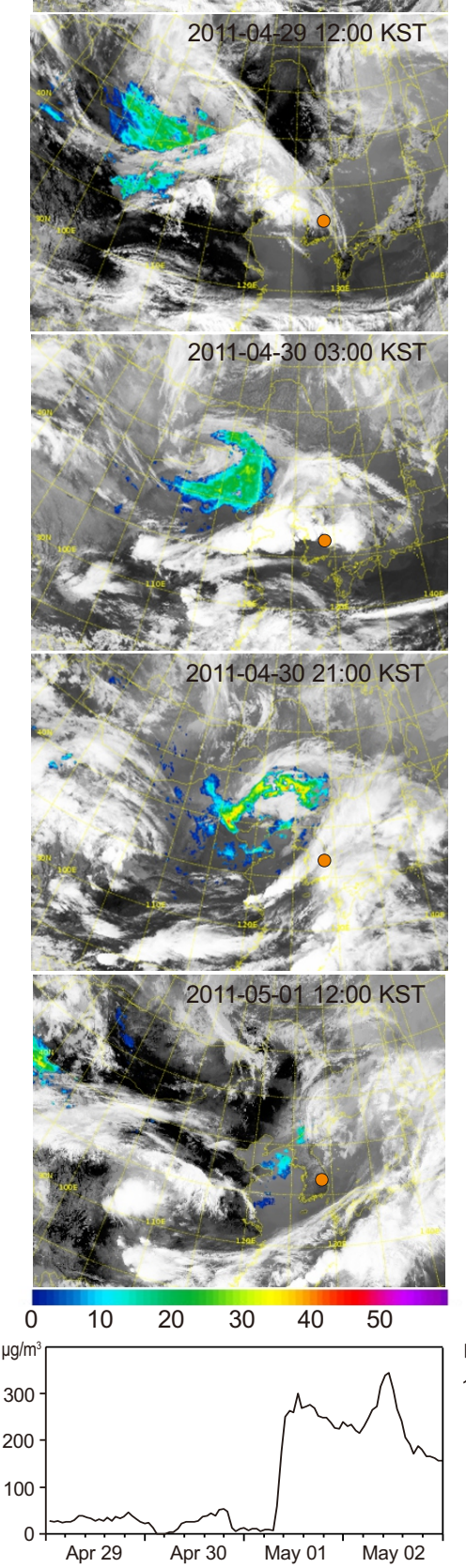

2010 Asian dust

MTSAT-1R Infrared Difference Dust Index
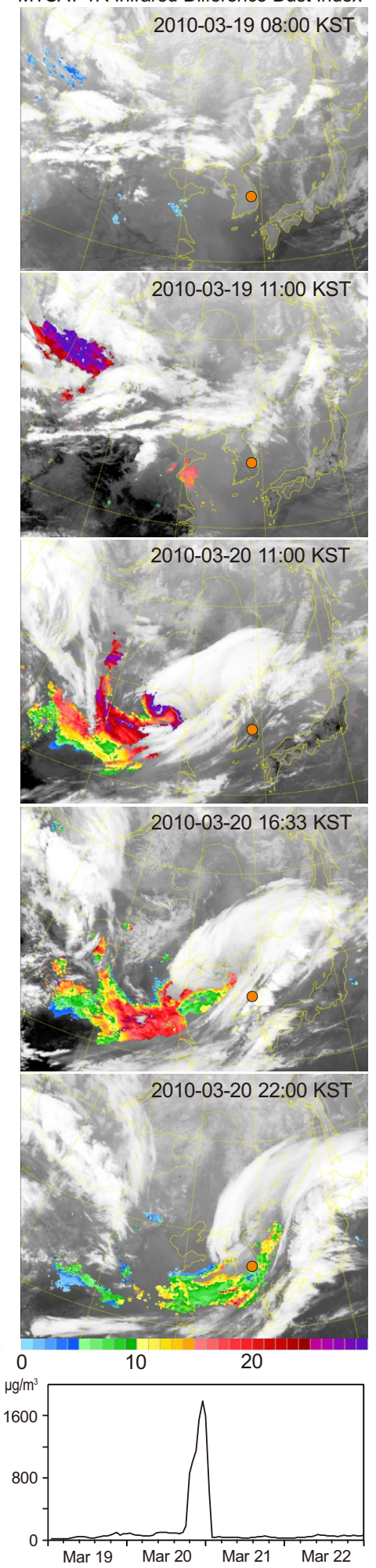

Fig. 1. COMS and MTSAT satellite images of the Asian dust index of three events observed in Korea. Solid orange circles are the TSP sampling sites in Korea. The graphs are plots of hourly $\mathrm{PM}_{10}$ concentrations over 4 days in the Korea Meteorological Administration aerosol monitoring stations near sampling sites. Red dots in the 2012 COMS images are the stations of the Korea-China joint Asian dust monitoring networks. 
on the time series of $\mathrm{PM}_{10}$ concentrations in Seoul (KMA, 2013). The time of flight was about $28 \mathrm{~h}$ for the migration of about $2000 \mathrm{~km}$. The duration of the Asian dust event was $4 \mathrm{~h}$ with a peak $\mathrm{PM}_{10}$ concentration of $220 \mu \mathrm{g} \mathrm{m}^{-3}$.

During the 2011 dust event, the images of COMS aerosol index images show that the dust outbreak occurred in the Gobi Desert $\left(40^{\circ}-45^{\circ} \mathrm{N}, 95^{\circ}-105^{\circ} \mathrm{E}\right)$ at around 12:00 KST on 29 April 2011 and the dust arrived at the sampling site (Andong) at 09:00 KST on 1 May 2011. The time of flight was about $45 \mathrm{~h}$ and the event lasted for about 3 days (ca. $62 \mathrm{~h}$ ) with a peak $\mathrm{PM}_{10}$ concentration of $344 \mu \mathrm{g} \mathrm{m}{ }^{-3}$.

MTSTR-1R IDDI images during the 2010 dust event show the dust outbreak in the Gobi Desert of southern Mongolia $\left(43^{\circ}-46^{\circ} \mathrm{N}, 100^{\circ}-110^{\circ} \mathrm{E}\right)$ at 11:00 KST on 19 March 2010. The dust arrived at around 22:00 KST on March 20 with the time of flight of about $35 \mathrm{~h}$. Time series of $\mathrm{PM}_{10}$ concentrations indicated short duration $(7 \mathrm{~h})$ at the sampling site (Andong, Korea) with a peak concentration of $1788 \mu \mathrm{g} \mathrm{m}^{-3}$. Although the sampling site used for the 2011 and 2010 dust events (Andong) was different from that used for the 2012 dust event, mineralogical and physical differences between Korean sites were not likely to be significant because Asian dust was a nationwide phenomenon over the Korean Peninsula in both events.

\section{Dust samples and methods}

The TSP Asian dust in 2012 was collected using a highvolume sampler (Thermo Scientific) fitted with a Tefloncoated borosilicate glass-fiber filter $(8 \mathrm{in} . \times 10 \mathrm{in}$. PALLFLEX membrane filters). The sampler was installed on a peak at Deokjeok Island $\left(190 \mathrm{~m}\right.$ above sea level, $37^{\circ} 13^{\prime} 59^{\prime \prime} \mathrm{N}$, $126^{\circ} 08^{\prime} 57^{\prime \prime} \mathrm{E}$ ) off the western coast of Korea, $85 \mathrm{~km}$ from Seoul. Sampling proceeded for 24 $\mathrm{h}$ from 09:00 on $31 \mathrm{March}$ to $08: 00$ on 1 April 2012. The flow rate of the sampler was adjusted to $250 \mathrm{~L} \mathrm{~min}^{-1}$ to avoid coagulation of particles on the filter surface. The measured TSP concentration for $24 \mathrm{~h}$ was $255 \mathrm{\mu g} \mathrm{m}^{-3}$. For comparison, we used TSP samples collected by the same procedure on 20 March 2010, and 1 May 2011 in Andong ( $\left.36^{\circ} 32^{\prime} 34^{\prime \prime} \mathrm{N}, 128^{\circ} 47^{\prime} 56^{\prime \prime} \mathrm{E}\right)$. The late Quaternary sediments of ancient Asian dust were sampled from a Paleolithic excavation site at Jeongok, Korea (Shin et al., 2004; Jeong et al., 2013). The exact ages of the sediments are debated but certainly younger than ca. $500000 \mathrm{yr}$ (Jeong et al., 2013). The silty sediments were prepared as polished thin sections after epoxy impregnation for comparison to Asian dust particles.

The physical and mineralogical characterization of the Asian dust was carried out by the electron microscopic analysis of single particles. Mineralogical analysis of bulk dust using X-ray powder diffraction was not possible due to the low mass of samples. For scanning electron microscopy (SEM), three layers of conductive sticky carbon tape were attached to $\mathrm{Cu}-\mathrm{Zn}$ stubs. The filter surface was touched lightly with car- bon tape. The filter surface was observed to change from light yellow brown to white, indicating transfer of the dust particles onto the carbon tape. Since our goal was to perform the entire morphological, chemical, and high-resolution electron microscopic analyses from one specimen, the particles were transferred onto the stable substrate of conductive sticky carbon tape. The dust particles collected on the filter were not suitable for the high resolution SEM and focused ion-beam (FIB) work due to charging even after metal coating.

After platinum coating for electrical conductivity, the morphology and chemistry of particles were analyzed with a TESCAN LMU VEGA microscope equipped with an IXRF energy dispersive X-ray spectrometer (EDXS) at $20 \mathrm{kV}$ acceleration voltage and $15 \mathrm{~mm}$ working distance. The IXRF EDXS detects elements from carbon. Numbers of analyzed particles were 3085, 1441, and 1689 in 2012, 2011, and 2010 dusts, respectively. High-resolution imaging of the surface microtextures of giant dust particles was performed with a JEOL JSM 6700F field emission gun microscope at $5 \mathrm{kV}$ acceleration voltage and $8 \mathrm{~mm}$ working distance. SEM work was performed at the Center for Scientific Instruments, Andong National University. Then, ultrathin slices (ca. $50 \mathrm{~nm}$ in thickness) of about ca. $6 \mu \mathrm{m} \times 6 \mu \mathrm{m}$ size were cut from dust particles using a SMI3050TB FIB instrument. Submicron minerals in the slices were characterized on the basis of lattice fringe spacing, electron diffraction, and chemical composition using a JEOL JEM3010 transmission electron microscope (TEM) at the National Center for Inter-University Research Facilities, Seoul National University and an Oxford EDXS system of a JEOL JEM 2010 TEM. The polished thin sections of the aeolian sediment from the Paleolithic site were examined in backscattered electron imaging mode using a TESCAN SEM instrument.

Single particle analysis of mineral dust employing SEMEDXS analysis is basically qualitative because of the irregular shape and wide size range of dust particles (Blanco et al., 2003; Kandler et al., 2007; Fletcher et al., 2011). In addition, the dust particles are mostly the agglomerates of subgrains of wide-ranging mineralogy and size in varying ratios. Thus, quantitative mineralogical analysis of single dust particle is practically impossible. However, the mineral types dominating dust particles can be reliably estimated from the EDX spectral pattern, compared with those of reference mineral particles. The mineralogical identification of the Asian dust particles was greatly facilitated by referring to quantitative mineralogical and microscopic data of the source soils and the Chinese loess deposited from the Asian dust around desert sources (Jeong, 2008; Jeong et al., 2008, 2011). Additionally, our SEM-EDXS identifications of Asian dust particles were confirmed by the TEM and EDXS analysis of the FIB slices of individual dust particles.

Dust particles were classified depending on their predominant mineral using EDX spectra following the identification procedure of Jeong (2008). Quartz and feldspars (Kfeldspar and plagioclase) were easily identified. However, 
mineralogical classification of clay minerals was more difficult due to their complex chemistry and structural diversity (Weaver, 1989). Fine-scale mixing of submicron platelets of clay minerals made classification more difficult. Clay minerals in dust and sediments include illite, smectite, illitesmectite mixed layers, kaolinite, vermiculite, and chlorite (Shi et al., 2005; Jeong and Chun, 2006; Jeong, 2008; Jeong et al., 2008, 2011). Kaolinite and chlorite were readily identified from their EDX spectra; however, illite, smectite, illitesmectite mixed layers, and vermiculite could not be positively identified because of their fine-scale mixing. Therefore, to avoid over-interpretation they were grouped into illite-smectite series clay minerals (ISCMs). The EDX spectra of many biotite and chlorite particles show signatures of partial weathering. Weathered biotite and chlorite that have partly lost of $\mathrm{K}, \mathrm{Mg}$, and $\mathrm{Fe}$ are often difficult to distinguish from ISCMs. Some muscovite grains with high $\mathrm{Mg}$ and $\mathrm{Fe}$ contents cannot be readily distinguished from illite. Thus, ISCMs, kaolinite, chlorite, muscovite, and biotite were further classed as total phyllosilicates. ISCM may be underestimated by counting the quartz and feldspar grains with ISCM coatings as quartz and feldspar particles, but overestimated by counting the ISCM agglomerates with quartz and feldspar inclusions as ISCM particles. Thus, both the errors will be partly canceled. Obviously, single-particle counting method is semiquantitative. Nevertheless, the results in Tables 2-4 are internally consistent, showing the distribution characteristics of minerals through different dust sizes and events. Jeong (2008) showed that mineral compositions obtained by the single-particle counting were consistent with those determined by X-ray diffraction analysis.

Particle diameters equivalent to a sphere were derived from 2-D images. The shape of particles in 2-D images approximates an ellipse (Reid et al., 2003). The orthogonal long and short dimensions of particle ellipses were measured using Corel Draw ${ }^{\circledR}$. The surface area and volume of the spheroids and the diameter of the equivalent spheres were calculated assuming spheroidal 3-D morphology of the particles (Reid et al., 2003). Large micaceous (muscovite, biotite, and weathered equivalents) flakes ( $>20 \mu \mathrm{m})$ could not be approximated by spheroidal morphology. Their volumes were calculated by multiplying the 2 -D area by thickness, assuming a $7: 1$ ratio of area-equivalent diameter to depth, because the ratios of micaceous flakes in Chinese loess ranged from 5:1 to 10: 1 (Jeong et al., 2008, 2011; Jeong and Lee, 2010). Particle sizes were divided into 12 size bins from 0.5 to $60 \mu \mathrm{m}$. The number, surface area, and volume fractions of the bins divided by the width of each bin were plotted against particle diameter on a logarithmic scale (Reist, 1993). Volume distribution is almost equivalent to mass distribution because the densities of the major minerals fall into a narrow range $\left(2.6-2.9 \mathrm{~g} \mathrm{~cm}^{-3}\right)$.
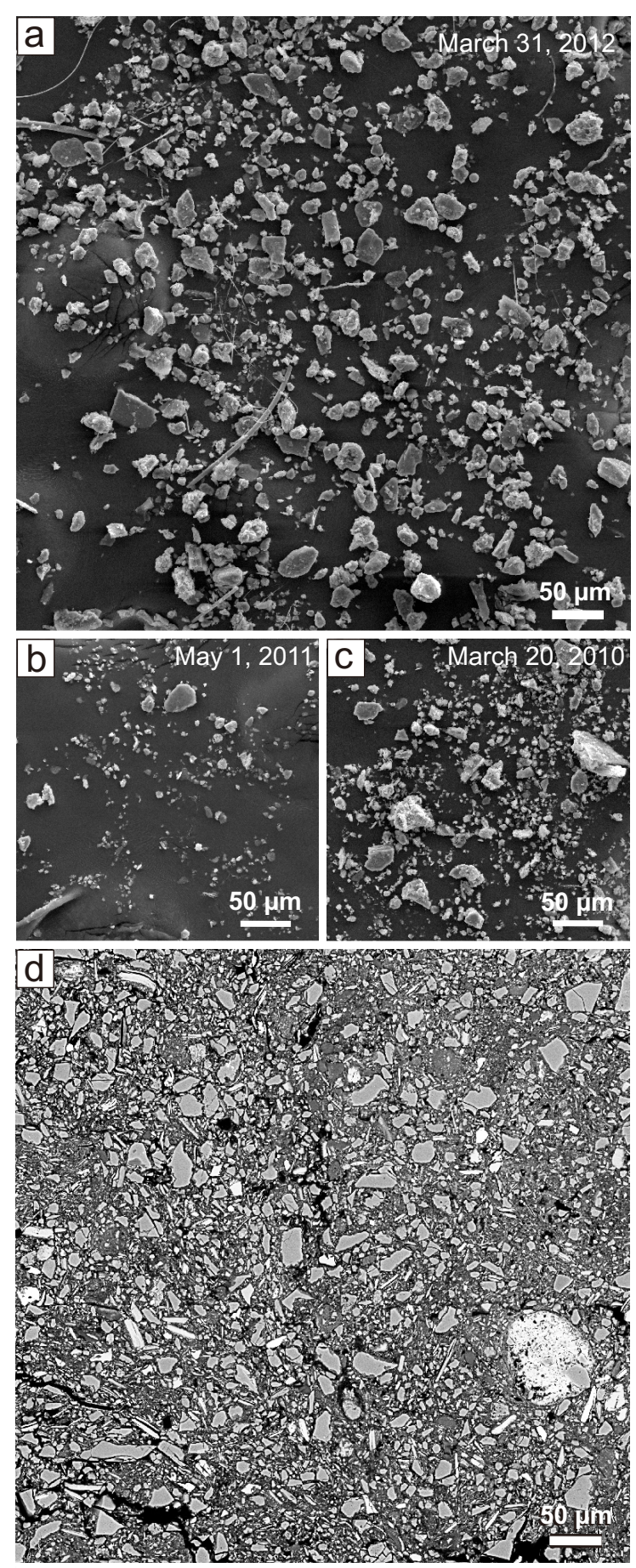

Fig. 2. Scanning electron micrographs of Asian dust particles. (a) Giant Asian dust particles, 31 March 2012, Deokjeok Island. Curved threads are contaminants from borosilicate glass-fiber filter. (b) Asian dust, 1 May 2011, Andong. (c) Asian dust, 20 March 2010, Andong. (d) Back-scattered electron image of the polished, thin section of aeolian sediment from the Jeongok Paleolithic site, showing quartz, K-feldspar, and plagioclase particles (bright gray contrast) in the fine clay matrix (dark gray contrast) with pores (black) impregnated with epoxy resin. 
Table 1. Particle number, surface area, and volume distribution of three Asian dusts from SEM measurements with basic properties.

\begin{tabular}{|c|c|c|c|c|c|c|}
\hline Diameter $(\mu \mathrm{m})$ & $\Delta \mathrm{N}$ & $\Delta \mathrm{N} /\left(\mathrm{N}_{T} \Delta \log D\right)$ & $\Delta \mathrm{S}\left(\mu \mathrm{m}^{2}\right)$ & $\Delta \mathrm{S} /\left(\mathrm{S}_{T} \Delta \log D\right)$ & $\Delta \mathrm{V}\left(\mu \mathrm{m}^{3}\right)$ & $\Delta \mathrm{V} /\left(\mathrm{V}_{T} \Delta \log D\right)$ \\
\hline \multicolumn{7}{|c|}{$2012\left(\mathrm{Md}=5.7 \mu \mathrm{m}, \mathrm{PM}_{10}=181 \mu \mathrm{g} \mathrm{m}^{-3}, \text { duration time }=4 \mathrm{~h}\right)^{\mathrm{a}}$} \\
\hline $0.5-1$ & 0 & 0.00 & 0 & 0.00 & 0 & 0.00 \\
\hline $1-2$ & 29 & 0.03 & 296 & 0.00 & 90 & 0.00 \\
\hline $2-3$ & 296 & 0.54 & 6174 & 0.04 & 2735 & 0.01 \\
\hline $3-4$ & 481 & 1.25 & 18424 & 0.18 & 10839 & 0.04 \\
\hline $4-6$ & 849 & 1.56 & 65891 & 0.45 & 55065 & 0.13 \\
\hline $6-8$ & 494 & 1.28 & 76220 & 0.74 & 88849 & 0.30 \\
\hline $8-10$ & 325 & 1.09 & 82309 & 1.03 & 121106 & 0.53 \\
\hline $10-15$ & 365 & 0.67 & 169056 & 1.16 & 347368 & 0.83 \\
\hline $15-20$ & 143 & 0.37 & 134371 & 1.30 & 388857 & 1.32 \\
\hline $20-40$ & 91 & 0.10 & 187604 & 0.76 & 829779 & 1.17 \\
\hline $40-60$ & 12 & 0.02 & 84314 & 0.58 & 681117 & 1.63 \\
\hline$n$ & 3085 & & & & & \\
\hline Giant-S \% & 16.5 & & 36.8 & & 29.1 & \\
\hline Giant-L \% & 3.3 & & 33.0 & & 59.8 & \\
\hline \multicolumn{7}{|c|}{$2011\left(\mathrm{Md}=2.9 \mu \mathrm{m}, \mathrm{PM}_{10}=273 \mu \mathrm{g} \mathrm{m}^{-3}\right.$, duration time $\left.=62 \mathrm{~h}\right)$} \\
\hline $0.5-1$ & 7 & 0.02 & 20 & 0.00 & 3 & 0.00 \\
\hline $1-2$ & 308 & 0.71 & 2635 & 0.12 & 744 & 0.03 \\
\hline $2-3$ & 438 & 1.73 & 8706 & 0.70 & 3729 & 0.26 \\
\hline $3-4$ & 310 & 1.72 & 11635 & 1.32 & 6762 & 0.65 \\
\hline $4-6$ & 265 & 1.04 & 18925 & 1.53 & 15393 & 1.05 \\
\hline $6-8$ & 70 & 0.39 & 10105 & 1.15 & 11486 & 1.11 \\
\hline $8-10$ & 25 & 0.18 & 6124 & 0.90 & 9145 & 1.14 \\
\hline $10-15$ & 13 & 0.05 & 5755 & 0.46 & 11886 & 0.81 \\
\hline $15-20$ & 4 & 0.02 & 4173 & 0.47 & 12723 & 1.23 \\
\hline $20-40$ & 1 & 0.00 & 2369 & 0.11 & 11096 & 0.44 \\
\hline $40-60$ & 0 & 0.00 & 0 & 0.00 & 0 & 0.00 \\
\hline$n$ & 1441 & & & & & \\
\hline Giant-S \% & 1.2 & & 14.1 & & 29.7 & \\
\hline Giant-L \% & 0.1 & & 3.4 & & 13.4 & \\
\hline \multicolumn{7}{|c|}{$2010\left(\mathrm{Md}=2.5 \mu \mathrm{m}, \mathrm{PM}_{10}=1518 \mu \mathrm{g} \mathrm{m}^{-3}\right.$, duration time $\left.=7 \mathrm{~h}\right)$} \\
\hline $0.5-1$ & 18 & 0.04 & 45 & 0.00 & 7 & 0.00 \\
\hline $1-2$ & 541 & 1.06 & 4864 & 0.19 & 1211 & 0.03 \\
\hline $2-3$ & 501 & 1.68 & 9713 & 0.65 & 4088 & 0.19 \\
\hline $3-4$ & 269 & 1.27 & 10158 & 0.96 & 5921 & 0.38 \\
\hline $4-6$ & 225 & 0.76 & 16917 & 1.13 & 14136 & 0.65 \\
\hline $6-8$ & 68 & 0.32 & 10346 & 0.97 & 12144 & 0.78 \\
\hline $8-10$ & 31 & 0.19 & 7365 & 0.89 & 10838 & 0.90 \\
\hline $10-15$ & 26 & 0.09 & 11961 & 0.80 & 25877 & 1.19 \\
\hline $15-20$ & 5 & 0.02 & 4716 & 0.44 & 13758 & 0.89 \\
\hline $20-40$ & 5 & 0.01 & 8995 & 0.35 & 36016 & 0.96 \\
\hline $40-60$ & 0 & 0.00 & 0 & 0.00 & 0 & 0.00 \\
\hline$n$ & 1689 & & & & & \\
\hline Giant-S \% & 1.8 & & 19.6 & & 32.0 & \\
\hline Giant-L \% & 0.3 & & 10.6 & & 29.0 & \\
\hline
\end{tabular}

${ }^{a} \mathrm{Md}$ is the median particle diameter on number basis. $\mathrm{PM}_{10}$ value is the mean of hourly measurements for $4 \mathrm{~h}$ around peak concentration (Korea Meteorological Administration, 2013). 
Table 2. Mineral compositions of Asian dust TSP collected on 31 March 2012 (unit in \%).

\begin{tabular}{|c|c|c|c|c|c|c|c|c|c|c|c|c|c|c|c|}
\hline \multirow[t]{2}{*}{$\begin{array}{l}\text { Mineral } \\
\text { Mineral }\end{array}$} & \multicolumn{3}{|c|}{$\begin{array}{c}\text { Total } \\
(n=2870)\end{array}$} & \multicolumn{3}{|c|}{$\begin{array}{l}\text { Fine }(<5 \mu \mathrm{m})^{1} \\
\quad(n=1555)^{2}\end{array}$} & \multicolumn{3}{|c|}{$\begin{array}{l}\text { Coarse }(5-10 \mu \mathrm{m}) \\
\quad(n=1130) \\
\end{array}$} & \multicolumn{3}{|c|}{$\begin{array}{c}\text { Giant-S }(10-20 \mu \mathrm{m}) \\
(n=490)\end{array}$} & \multicolumn{3}{|c|}{$\begin{array}{c}\text { Giant-L }(>20 \mu \mathrm{m}) \\
(n=95)\end{array}$} \\
\hline & No. & Area & Vol. & No. & Area & Vol. & No. & Area & Vol. & No. & Area & Vol. & No. & Area & Vol. \\
\hline \multicolumn{16}{|l|}{ Phyllosilicate } \\
\hline Total & 52.3 & 52.7 & 52.1 & 52.0 & 53.5 & 54.2 & 54.2 & 55.1 & 54.3 & 49.2 & 50.7 & 48.2 & 49.5 & 53.4 & 53.9 \\
\hline $\mathrm{ISCMs}^{3}$ & 42.1 & 39.2 & 36.1 & 42.4 & 43.4 & 44.1 & 43.2 & 43.3 & 42.5 & 40.2 & 40.8 & 37.9 & 33.7 & 33.4 & 33.6 \\
\hline Kaolinite & 2.4 & 3.0 & 4.5 & 3.5 & 2.5 & 2.9 & 1.7 & 1.6 & 1.7 & 1.0 & 1.2 & 1.2 & 3.2 & 6.5 & 7.0 \\
\hline Muscovite & 1.5 & 2.6 & 3.5 & 0.7 & 0.8 & 0.7 & 1.9 & 2.5 & 2.5 & 1.8 & 1.4 & 1.3 & 3.2 & 4.4 & 5.1 \\
\hline Chlorite & 3.5 & 3.0 & 2.6 & 3.1 & 4.1 & 3.7 & 4.3 & 4.3 & 4.2 & 2.7 & 3.0 & 3.5 & 3.2 & 2.0 & 1.7 \\
\hline Biotite & 2.9 & 4.9 & 5.4 & 2.2 & 2.6 & 2.8 & 3.1 & 3.4 & 3.4 & 3.5 & 4.3 & 4.3 & 6.3 & 7.1 & 6.5 \\
\hline Talc & 0.0 & 0.0 & 0.0 & 0.1 & 0.1 & 0.1 & 0.0 & 0.0 & 0.0 & 0.0 & 0.0 & 0.0 & 0.0 & 0.0 & 0.0 \\
\hline \multicolumn{16}{|l|}{ Other silicates } \\
\hline Quartz & 19.7 & 21.1 & 25.0 & 17.9 & 17.6 & 17.7 & 20.1 & 20.1 & 20.7 & 22.4 & 21.5 & 20.8 & 22.1 & 21.8 & 28.5 \\
\hline Plagioclase & 10.3 & 11.9 & 10.1 & 9.1 & 9.7 & 9.1 & 11.2 & 11.2 & 11.4 & 10.8 & 11.3 & 13.8 & 10.5 & 13.6 & 7.8 \\
\hline K-feldspar & 5.2 & 5.0 & 4.4 & 5.0 & 5.3 & 5.1 & 4.2 & 4.0 & 4.0 & 7.6 & 6.8 & 7.2 & 6.3 & 3.5 & 2.9 \\
\hline Amphibole & 0.9 & 0.9 & 0.8 & 0.8 & 1.1 & 0.8 & 0.8 & 0.8 & 0.9 & 1.0 & 0.7 & 0.7 & 2.1 & 1.1 & 0.8 \\
\hline Pyroxene & 0.1 & 0.2 & 0.3 & 0.0 & 0.0 & 0.0 & 0.1 & 0.1 & 0.1 & 0.0 & 0.0 & 0.0 & 1.1 & 0.6 & 0.5 \\
\hline Titanite & 0.2 & 0.2 & 0.3 & 0.3 & 0.4 & 0.3 & 0.1 & 0.1 & 0.1 & 0.0 & 0.0 & 0.0 & 1.1 & 0.7 & 0.6 \\
\hline Zoisite & 0.4 & 0.4 & 0.1 & 0.2 & 0.1 & 0.2 & 0.6 & 0.5 & 0.5 & 0.4 & 0.7 & 0.2 & 0.0 & 0.0 & 0.0 \\
\hline \multicolumn{16}{|l|}{ Non-silicates } \\
\hline Calcite & 6.7 & 6.0 & 5.9 & 7.2 & 6.8 & 6.5 & 6.3 & 6.1 & 6.1 & 6.3 & 6.4 & 7.1 & 7.4 & 5.4 & 5.1 \\
\hline Dolomite & 1.2 & 0.5 & 0.4 & 2.0 & 1.5 & 1.7 & 0.8 & 0.7 & 0.7 & 0.6 & 0.7 & 0.8 & 0.0 & 0.0 & 0.0 \\
\hline Iron oxides & 1.6 & 0.6 & 0.4 & 2.7 & 2.0 & 2.0 & 0.8 & 0.7 & 0.6 & 1.0 & 0.8 & 0.8 & 0.0 & 0.0 & 0.0 \\
\hline $\mathrm{Fe}-\mathrm{Ti}$ oxides & 0.4 & 0.2 & 0.1 & 0.4 & 0.5 & 0.4 & 0.4 & 0.4 & 0.4 & 0.4 & 0.3 & 0.2 & 0.0 & 0.0 & 0.0 \\
\hline Ti oxides & 0.1 & 0.0 & 0.0 & 0.3 & 0.4 & 0.3 & 0.1 & 0.1 & 0.1 & 0.0 & 0.0 & 0.0 & 0.0 & 0.0 & 0.0 \\
\hline Gypsum & 0.8 & 0.1 & 0.0 & 1.9 & 1.0 & 1.2 & 0.1 & 0.0 & 0.0 & 0.0 & 0.0 & 0.0 & 0.0 & 0.0 & 0.0 \\
\hline Apatite & 0.1 & 0.1 & 0.0 & 0.2 & 0.1 & 0.2 & 0.1 & 0.1 & 0.1 & 0.2 & 0.1 & 0.1 & 0.0 & 0.0 & 0.0 \\
\hline Pyrite & 0.0 & 0.0 & 0.0 & 0.1 & 0.2 & 0.2 & 0.0 & 0.0 & 0.0 & 0.0 & 0.0 & 0.0 & 0.0 & 0.0 & 0.0 \\
\hline
\end{tabular}

${ }^{1}$ Particle diameter of equivalent sphere.

${ }^{2}$ Number of analyzed particles.

${ }^{3}$ Illite-smectite series clay minerals (illite, smectite, and their mixed layers).

\section{Results}

\subsection{Particle size}

SEM images revealed that the particles of 2012 dust were much larger than those in 2010 and 2011 dusts. Giant particles were common in the 2012 dust (Fig. 2a), while they were rare in the 2010 and 2011 dusts (Fig. 2b, c). Number distributions of the three dusts showed roughly log-normal distributions (Fig. 3, Table 1). The median equivalent-sphere diameter of the 2012 dust was $5.7 \mu \mathrm{m}$ and the maximum was $60 \mu \mathrm{m}$. The proportion of giant particles (giant-S and giant-L) was $20 \%$ on a number basis, but they contributed $89 \%$ of the total volume. Giant-L particles occupied $60 \%$ of the volume. In contrast, the median diameters of the 2010 and 2011 dusts were 2.5 and $2.9 \mu \mathrm{m}$, respectively. The number proportions of the giant particles were only 2 and $1 \%$ in the 2010 and 2011 dusts, respectively, while the respective volume proportions were 61 and $43 \%$. The volume contributions of giant-L particles were 29 and $13 \%$ in both dusts. SEM backscattered electron images of thin sections of the sediment (Fig. 2d) identified giant particles of quartz and feldspar enclosed in the clay matrix.

\subsection{Particle mineralogy}

Phyllosilicates were the most common mineral group in 2012 dust particles (Table 2). The number and volume abundance of total phyllosilicates were 52.3 and $52.1 \%$, respectively. ISCMs were the major phyllosilicates $(42.1 \%$ of number abundance and $36.1 \%$ of volume abundance), followed by muscovite, biotite, and chlorite. Biotite and chlorite were partly weathered as shown in the loss of cations including $\mathrm{K}, \mathrm{Mg}$, and $\mathrm{Fe}$. The other silicates were quartz (19.7 and $25.0 \%$ ), plagioclase (10.3 and $10.1 \%$ ), K-feldspar (5.2 and $4.4 \%)$, and amphibole $(0.9$ and $0.8 \%)$. Calcite was the major carbonate $(6.7$ and $5.9 \%)$ with a minor dolomite content $(1.2$ and $0.4 \%)$. The number and volume ratios of dolomite to calcite were about 0.18 and 0.06 , respectively. $\mathrm{Fe}, \mathrm{Ti}$, and iron-titanium oxides were minor components in Asian dust with total content of about $1 \%$.

Mineral composition varied little throughout the four size bins (Table 2). The abundance of ISCMs decreased from the fine bin $(44.1 \%)$ to giant-L bin (33.6\%). However, increases 

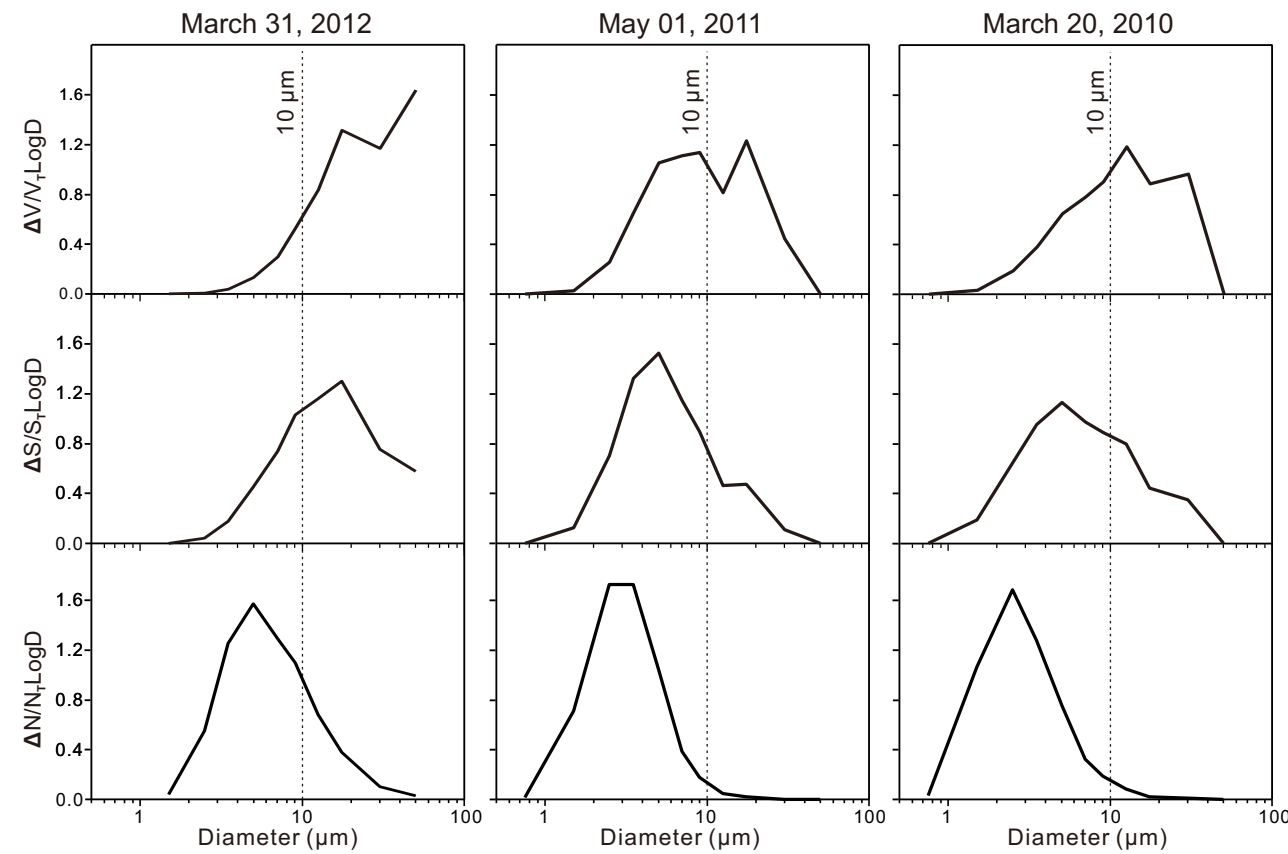

Fig. 3. Number, surface area, and volume-size distributions of three Asian dusts measured by scanning electron microscopy.

Table 3. Particle number, surface area, and volume contributions of four size bins to major minerals in the Asian dust TSP collected on 31 March 2012 (unit in \%).

\begin{tabular}{|c|c|c|c|c|c|c|c|c|c|c|c|c|c|c|c|}
\hline \multirow{2}{*}{ Mineral } & \multicolumn{5}{|c|}{ Number } & \multicolumn{5}{|c|}{ Area } & \multicolumn{5}{|c|}{ Volume } \\
\hline & $\mathrm{F}^{2}$ & $\mathrm{C}$ & GS & GL & Sum & $\mathrm{F}$ & $\mathrm{C}$ & GS & GL & Sum & $\mathrm{F}$ & $\mathrm{C}$ & GS & GL & Sum \\
\hline \multicolumn{16}{|c|}{ Phyllosilicates } \\
\hline Total & 40.0 & 40.8 & 16.0 & 3.1 & 100 & 4.6 & 24.4 & 38.8 & 32.2 & 100 & 2.2 & 10.8 & 29.9 & 57.1 & 100 \\
\hline ISCMs $^{1}$ & 40.6 & 40.4 & 16.3 & 2.7 & 100 & 5.0 & 25.8 & 42.0 & 27.1 & 100 & 2.6 & 12.2 & 33.9 & 51.3 & 100 \\
\hline Kaolinite & 60.3 & 27.9 & 7.4 & 4.4 & 100 & 3.7 & 12.5 & 15.4 & 68.5 & 100 & 1.4 & 4.0 & 8.5 & 86.2 & 100 \\
\hline Muscovite & 19.0 & 52.4 & 21.4 & 7.1 & 100 & 1.4 & 22.5 & 22.0 & 54.1 & 100 & 0.4 & 7.3 & 11.9 & 80.3 & 100 \\
\hline Chlorite & 35.6 & 48.5 & 12.9 & 3.0 & 100 & 6.1 & 33.0 & 40.5 & 20.4 & 100 & 3.0 & 16.9 & 44.1 & 36.0 & 100 \\
\hline Biotite & 30.1 & 42.2 & 20.5 & 7.2 & 100 & 2.4 & 16.1 & 35.4 & 46.1 & 100 & 1.1 & 6.5 & 25.5 & 66.9 & 100 \\
\hline \multicolumn{16}{|c|}{ Other silicates } \\
\hline Quartz & 36.6 & 40.2 & 19.5 & 3.7 & 100 & 3.8 & 22.2 & 41.1 & 32.8 & 100 & 1.5 & 8.6 & 26.9 & 63.0 & 100 \\
\hline Plagioclase & 35.6 & 43.1 & 18.0 & 3.4 & 100 & 3.7 & 21.9 & 38.2 & 36.2 & 100 & 1.9 & 11.6 & 43.8 & 42.6 & 100 \\
\hline K-feldspar & 38.9 & 32.2 & 24.8 & 4.0 & 100 & 4.8 & 18.6 & 54.4 & 22.2 & 100 & 2.5 & 9.4 & 52.2 & 35.9 & 100 \\
\hline Amphibole & 36.0 & 36.0 & 20.0 & 8.0 & 100 & 5.5 & 22.0 & 33.4 & 39.0 & 100 & 2.1 & 11.6 & 28.3 & 58.0 & 100 \\
\hline \multicolumn{16}{|l|}{ Non-silicates } \\
\hline Calcite & 43.2 & 37.0 & 16.1 & 3.6 & 100 & 5.1 & 23.5 & 43.0 & 28.3 & 100 & 2.4 & 10.7 & 39.2 & 47.7 & 100 \\
\hline Dolomite & 65.7 & 25.7 & 8.6 & 0.0 & 100 & 13.0 & 34.0 & 52.9 & 0.0 & 100 & 9.9 & 19.8 & 70.4 & 0.0 & 100 \\
\hline Iron oxides & 68.9 & 20.0 & 11.1 & 0.0 & 100 & 15.7 & 26.6 & 57.7 & 0.0 & 100 & 11.6 & 16.5 & 71.9 & 0.0 & 100 \\
\hline Sum & 40.2 & 39.4 & 17.1 & 3.3 & 100 & 4.5 & 23.3 & 40.3 & 31.8 & 100 & 2.1 & 10.3 & 32.3 & 55.2 & 100 \\
\hline
\end{tabular}

${ }^{1}$ Illite-smectite series clay minerals (illite, smectite, and their mixed layers).

${ }^{2} \mathrm{~F}$ is fine $(<5 \mu \mathrm{m}), \mathrm{C}$ is coarse $(5-10 \mu \mathrm{m})$, GS is giant-S $(10-20 \mu \mathrm{m})$, and GL is giant-L $(>20 \mu \mathrm{m})$.

in muscovite and biotite contents result in little variation of total phyllosilicate content over the size bins. Quartz content increased from 17.7 to $28.5 \%$. The fine size bin was relatively enriched with trace minerals, such as iron oxides, titanium oxides, dolomite, and gypsum.
The contributions of size bins to the number, surface area, and volume of each mineral or mineral group are listed in Table 3. Their variations with minerals were not significant regardless of number, surface area, and volume. Giant particles accounted for $70-75 \%$ of the volume of mineral and 
Table 4. Mineral number compositions of Asian dust TSPs collected on 1 May 2011 and 20 March 2010 (\%).

\begin{tabular}{lll}
\hline Mineral & $2011(n=981)$ & $2010(n=953)$ \\
\hline Phyllosilicates & & \\
Total & 59.2 & 60.3 \\
ISCMs 1 & 48.2 & 49.4 \\
Kaolinite & 1.6 & 1.7 \\
Muscovite & 0.3 & 0.9 \\
Chlorite & 4.5 & 5.7 \\
Biotite & 4.6 & 2.4 \\
Talc & 0.0 & 0.2 \\
Other silicates & & \\
Quartz & 16.8 & 16.9 \\
Plagioclase & 10.5 & 10.0 \\
K-feldspar & 4.3 & 3.0 \\
Amphibole & 0.6 & 0.4 \\
Pyroxene & 0.0 & 0.0 \\
Titanite & 0.0 & 0.0 \\
Zoisite & 0.4 & 0.2 \\
Non-silicates & & \\
Calcite & 5.8 & 5.7 \\
Dolomite & 0.2 & 0.9 \\
Iron oxides & 0.6 & 0.8 \\
Fe-Ti oxides & 0.1 & 0.3 \\
Ti oxides & 0.2 & 0.1 \\
Gypsum & 0.7 & 1.1 \\
Barite & 0.1 & 0.0 \\
Pyrite & 0.2 & 0.0 \\
Apatite & 0.1 & \\
\hline
\end{tabular}

* Illite, smectite, and illite-smectite mixed-layer clay minerals.

mineral groups, while the volume contribution of the fine size bins was usually $<3 \%$, e.g., the contribution of giant size bins to ISCM content was $85.2 \%$ on a volume basis, but only $2.7 \%$ on a number basis. However, the contributions of fine size bins to the volumes of dolomite $(9.9 \%)$ and iron oxides $(11.6 \%)$ were higher than those of other minerals.

Mineral number compositions in the 2010 and 2011 dusts were similar to the compositions of 2012 dust (Table 4). However, the 2010 and 2011 dusts were more enriched with ISCMs by about $10 \%$ compared with the 2012 dust.

\subsection{Microtextures and submicron mineralogy of giant particles}

The surface details of giant-L particles were imaged using high-resolution SEM. Quartz (Fig. 4a, b) and plagioclase (Fig. 4c) have surface coatings of micron- to submicron-sized fine clay platelets. Calcite nanofibers were closely associated with clay minerals as cross-linked intergrowth (Fig. 4a, b) or single fibers on the surfaces of clay platelets (Fig. 4c). Fine clay platelets agglomerated to form giant clayey particles (Fig. 4d, e). Cross-linked intergrowth of calcite nanofibers was also found in the interstices of clayey agglomerates
(Fig. 4d, e). Some coarse kaolinite was present with coatings of calcite nanofibers (Fig. 4f), resulting in enhanced kaolinite content in the giant-L size bin (Table 2).

TEM images of the FIB slice of the clayey agglomerate giant particle in Fig. 4e showed a fine-scale agglomeration of ISCMs with submicron grains of quartz, Kfeldspar, and chlorite (Fig. 5a1). Lattice-fringe imaging of the ISCMs showed the basal spacings of ca. $1.0-1.2 \mathrm{~nm}$ (Fig. 5a2). Nanofiber calcite grains of elongated morphology were closely admixed with the ISCM clays in a submicron scale (Fig. 5a3, 5a4). The lattice fringe of ca. $0.3 \mathrm{~nm}$ (Fig. 5a5) and EDX spectrum (Fig. 5a6) confirmed calcite. TEM image of the FIB slice of the quartz particle in Fig. 4b showed thin ISCM clay layers (ca. $1 \mu \mathrm{m}$ thickness) covering quartz grain (Fig. 5b1, 5b2). The ISCMs contain a high amount of Fe (Fig. 5b3). The range of Fe content (8 analyses) of ISCMs determined by EDXS was ca. 3-14 w/w \% (average $7 \mathrm{w} / \mathrm{w} \%$ ). Although the dominant clay minerals were ISCMs (Fig. 5b4), kaolinite and chlorite were also admixed as shown in the lattice fringes of 0.7 and $1.4 \mathrm{~nm}$, respectively (Fig. 5b5, 5b6).

\section{Discussion}

\subsection{Comparison of SEM particle sizes to optical particle counter data}

SEM images and particle-size data indicated relatively coarse characteristics of the 2012 dust, compared with 2010 and 2011 dust. Particle-size data measured from SEM images were compared with real-time data produced with an optical particle counter (OPC) (GRIMM Aerosol Technik Model 180) at the Korea Meteorological Administration Asian dust monitoring station in Seoul. The OPC reports particle numbers over 30 size bins from 0.25 to $32 \mu \mathrm{m}$. The coarse characteristics of the 2012 dust were confirmed by the volume distributions of three Asian dusts measured using OPC (Fig. 6). The volume distributions of the 2012 dust revealed almost monotonic increase toward larger sizes, while distributions of 2010 and 2011 dusts had modes of around $3 \mu \mathrm{m}$. The volume portions of giant particles were 64,8 , and $39 \%$ in 2012, 2011, and 2010 dusts, respectively, while those derived from SEM measurements were 89,43 , and $61 \%$, respectively.

The orders of enrichment of giant particles were consistent in both SEM and OPC measurements, with highest concentration in the 2012 dust and lowest concentration in the 2011 dust. However, the OPC data were shifted toward fine sizes relative to SEM data. Reid et al. (2003) observed similar features in comparison between SEM and aerodynamic particle size data for Saharan dust. The differences are attributed to assumptions made for SEM measurements, measurement objects, or site-specific factors between sampling and OPC installation site. SEM measurements assume spheroidal dust particle morphology. The actual morphology 

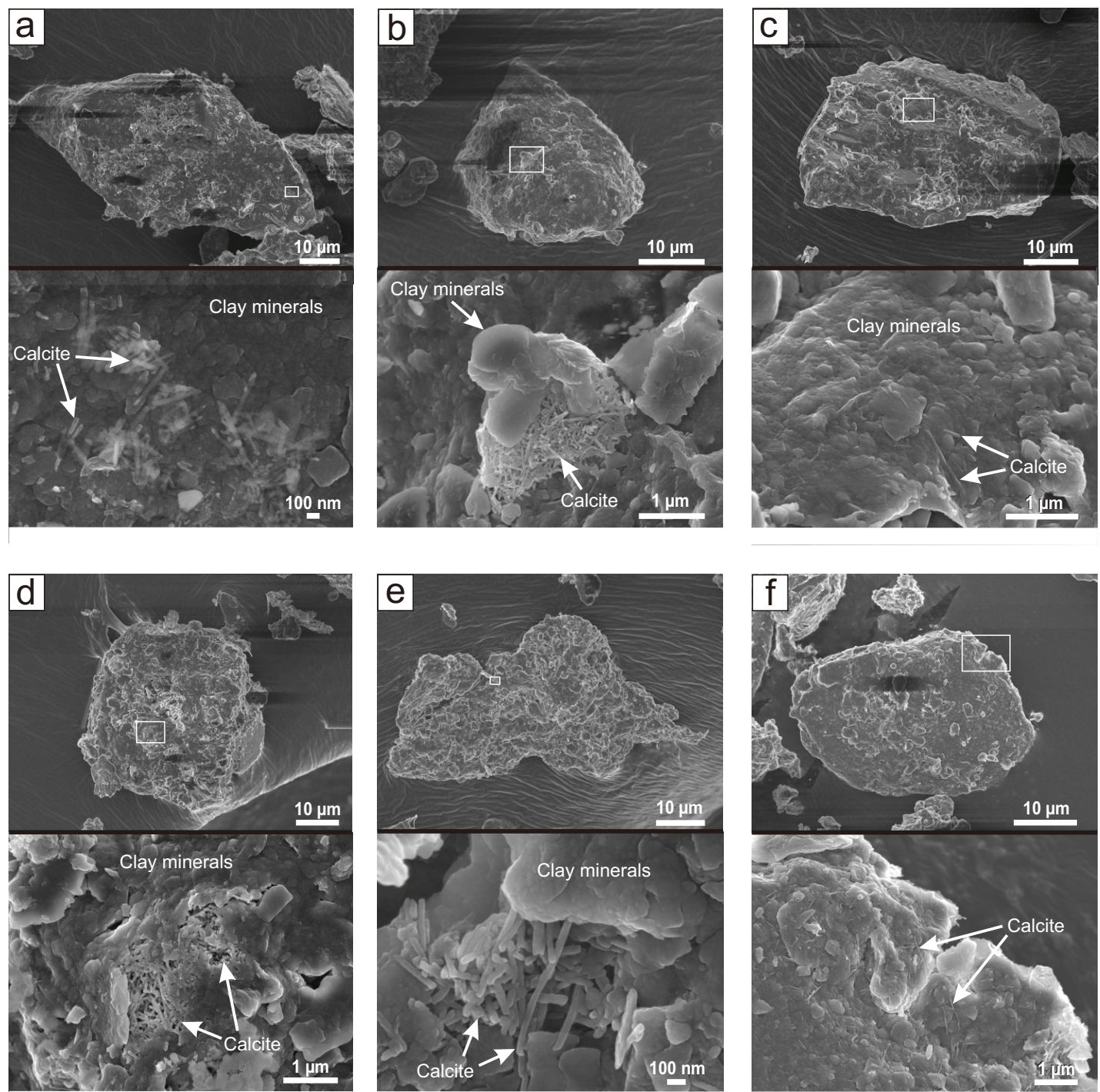

Fig. 4. High-resolution SEM images of the surfaces of giant-L dust particles. Bottom image was magnified from the box in the upper image. (a, b) Quartz particles coated with thin layers of clay platelets and intergrowth of calcite nanofibers. (c) Plagioclase coated with thin layers of clay platelets and calcite nanofibers. (d, e) Agglomerates of clay platelets with intergrowths of calcite nanofibers. (f) Kaolinite with calcite nanofibers.

of many particles is not spheroidal but is better approximated as an ellipsoid of which the longer axes are parallel to the filter surface. We have no information regarding the third shortest dimension and therefore the actual diameters would be smaller than those measured by SEM. The OPC cannot distinguish mineral particles from biogenic, marine, and pollutant particles. However, our SEM measurements excluded sea salt and most submicron particles of organic/inorganic pollutants and soot. The volume of giant-L size particles increased markedly in the OPC data for 2010 dust (Fig. 6). This is possibly due to the presence of coarse non-mineral particles, such as pollens, which cannot be distinguished by OPC. However, plants flowering in March are rare around the sampling site (Seoul). Thus, the OPC volume distribution in- dicates the coarser characteristics of the 2010 dust in Seoul, compared with the SEM size distribution in Andong.

The population of giant particles in the 2012 dust was larger than those in 2011 and 2010 dusts. SEM analysis of single particles enabled determination of mineralogy, chemistry, and size distribution of coarse mineral dust, distinguishing them from non-mineral particles. Combined application of SEM and the wide-ranging particle counter installed at the same sampling site optimizes systematic characterization of mineral dusts laden with large particles. 
(a)
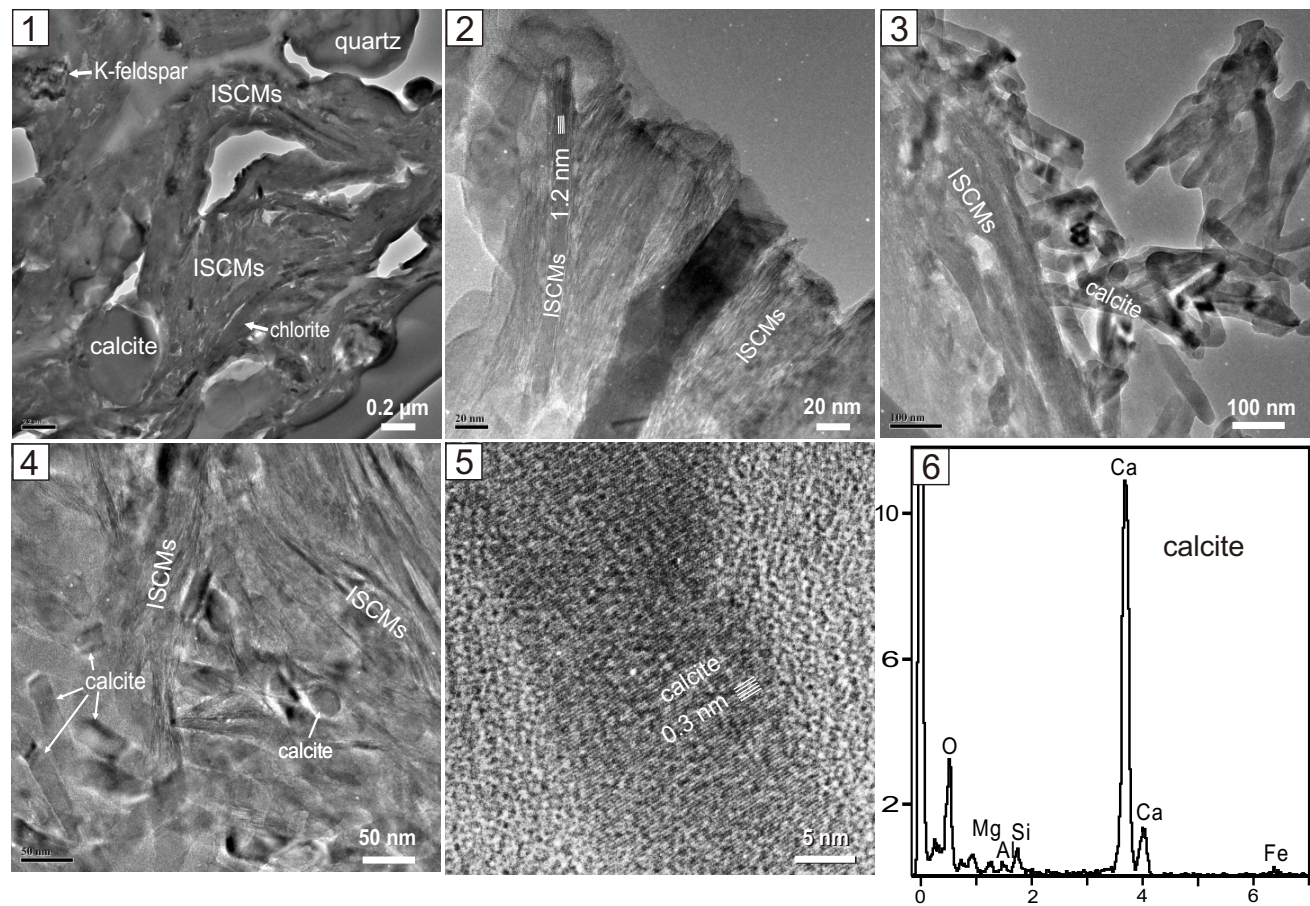

$\mathrm{KeV}$
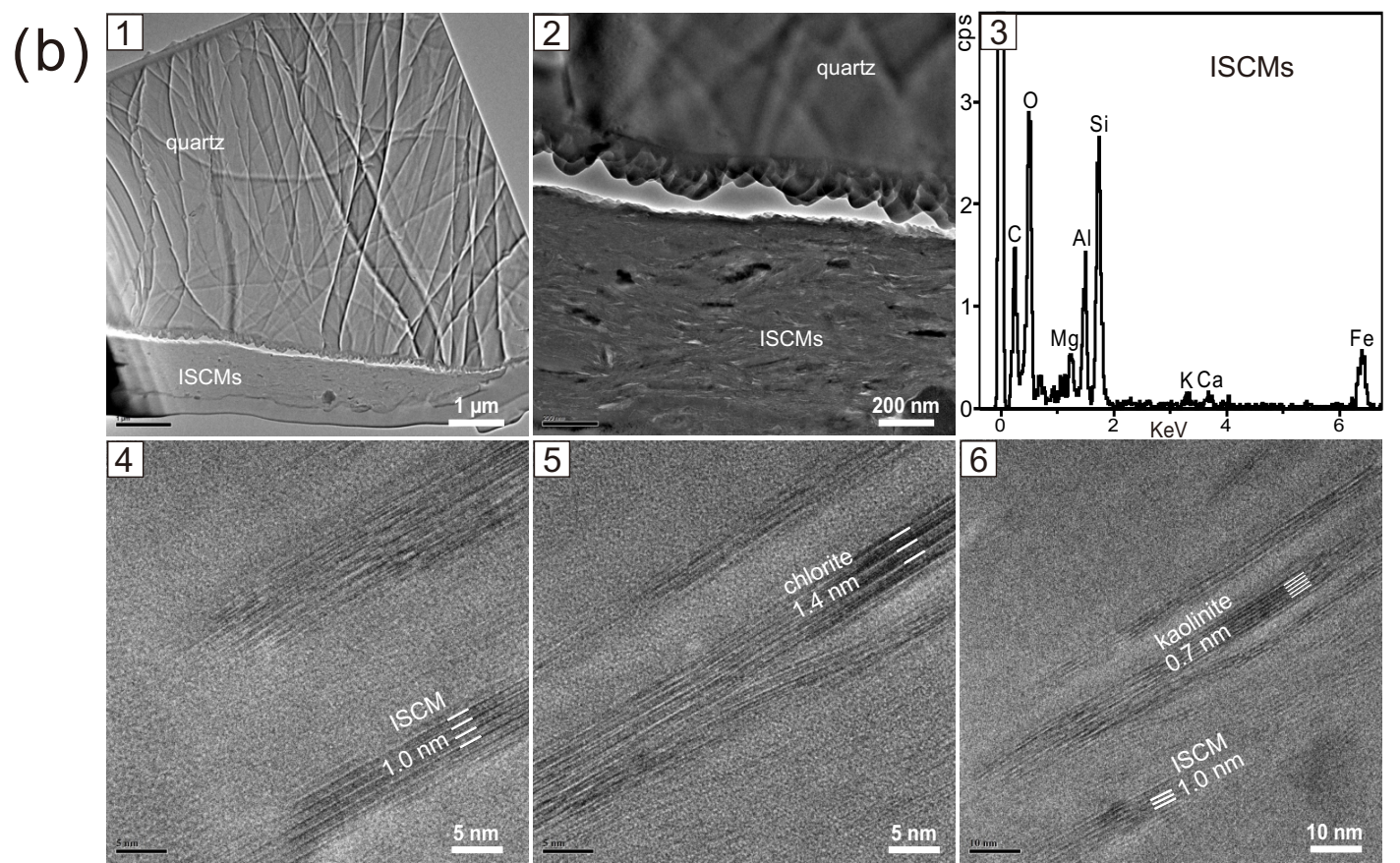

Fig. 5. TEM microtextures and lattice fringe images of giant dust particles with EDX spectra. (a) FIB slice of the clayey agglomerate dust particle in Fig. 4e. (b) FIB slice of the quartz dust particle in Fig. 4b.

\subsection{Mineral compositions and particle sizes}

Fine clay minerals (ISCMs) consistently decreased in the larger size bins with general increases in quartz, plagioclase, biotite, and muscovite (Table 2). Concentrations of quartz, plagioclase, biotite, and muscovite in the giant-L size bin were related to their usual occurrence in coarse-grained igneous and metamorphic bedrocks. Despite these mineralogical variations, the mineral compositions were highly uniform from fine to giant- $\mathrm{L}$ particles as shown by the large ISCM volume of the giant-L size bin (33.6\%). This was primarily 

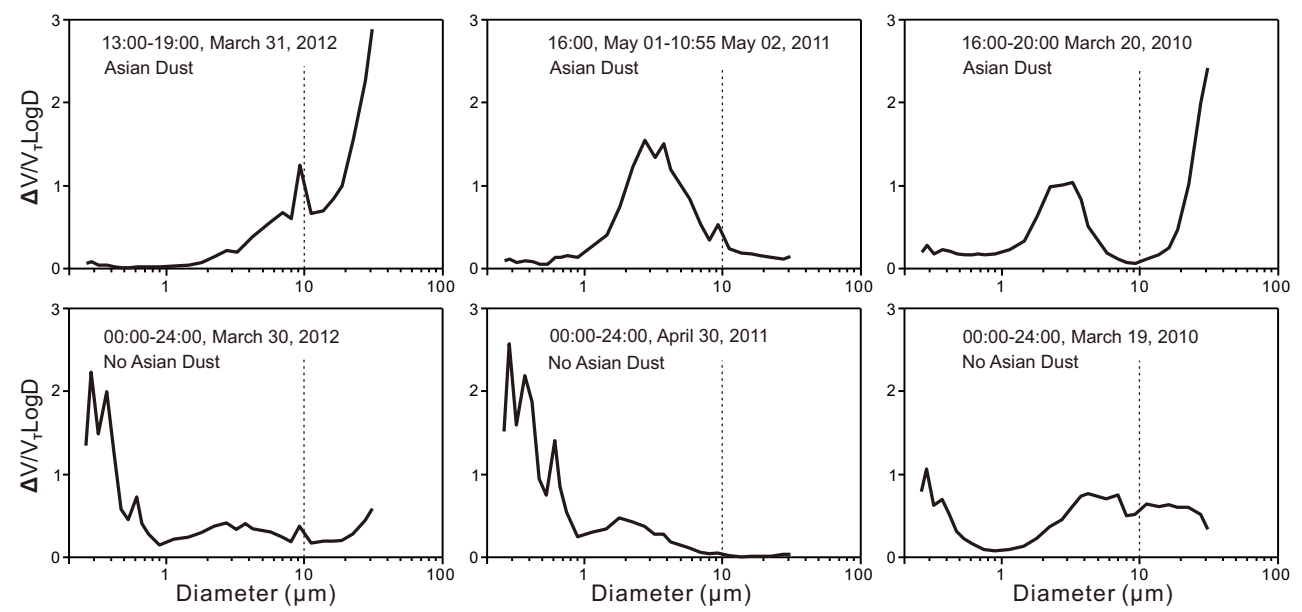

Fig. 6. Volume-size distributions of three Asian dusts measured with an optical particle counter at the Korea Meteorological Administration Asian dust monitoring station in Seoul, compared with those of non-Asian dust days. Dust event periods in Korea Standard Time.

attributed to the occurrence of large agglomerates of fine clay minerals (Fig. 4d, e) and thin coatings on large quartz and feldspar grains (Figs. 4a-c). ISCMs were the most common mineral group throughout all the size bins, even the giant-L size bin (Table 2). Thus, most of the volume (mass) of fine clay minerals was transported in the form of giant particles. Giant-S and giant-L particles contained 34 and $51 \%$ of the ISCMs, respectively (Table 3).

\subsection{Nanoscale evidence of the remote origin of giant particles}

The size of dust particles transported over $1000 \mathrm{~km}$ is generally below $10 \mu \mathrm{m}$ (Tegen and Lacis, 1996). Giant particles are normally transported and deposited over short distances of a few hundred kilometers (Pye, 1995). Thus, it is difficult to determine whether giant dust particles, particularly at sites on land that are distant from the source, are remote or local. Previous studies at sites on land suggested that Asian dust particles $>10 \mu \mathrm{m}$ may have been derived from local sources (Chun et al., 2001). The origin of giant dust particles can be confirmed from the nanoscopic features acquired during the chemical weathering in source soils.

Minerals in soils are subjected to chemical weathering. Primary minerals derived from the erosion of rocks are unstable and dissolved by reacting with soil solutions, while secondary minerals are crystallized, depending on their solubility. The intensity of chemical weathering is largely dependent upon annual precipitation and temperature, ranging from the least weathering of primary minerals in arid soils to complete decomposition in tropical soils. The stability of minerals against chemical weathering is very diverse (Brady, 1990), e.g., on the Chinese loess plateau along the climatic gradients, primary minerals were sequentially weathered in a progressive fashion with increasing annual precipitation eastward in the order of calcite, dolomite, biotite, illite, chlorite, amphibole, and plagioclase (Jeong et al., 2011). Calcite is more susceptible to chemical weathering than other major primary minerals. Thus, even in arid environments, coarse primary calcite in soils could react with water supplied by intermittent rain or melt water. However, leached $\mathrm{Ca}^{2+}$ ions are rapidly reprecipitated to form secondary calcites in soils due to high evaporation rates.

The average content of primary calcite in the western $\mathrm{Ji}$ uzhoutai loess was about $11.7 \%$ (Jeong et al., 2008). Thus, calcite dissolution and reprecipitation are the major weathering processes in the arid soils of Asian dust sources. The morphological characteristics of secondary calcite are greatly different from those of primary calcite. One of the major forms of secondary calcite is a nano-sized fiber in comparison to micron-sized irregular primary calcite (Jeong and Chun, 2006; Jeong, 2008; Jeong et al., 2011). In the desert sands and loess silts of Asian dust sources, these nanofibers occurred only in samples containing coarse primary calcite particles derived from rocks, indicating that the primary calcite particles were partly dissolved during the occasional rainfalls, and reprecipitated as nanofibers from evaporating soil solutions (Jeong and Chun, 2006).

The precipitation of nanofiber calcites from soil solutions results in the pervasive infilling of the interstices of coarser soil particles, together with submicron clay minerals. Thus, the surfaces of the source soil particles are commonly associated with calcite nanofibers scattered individually or forming their own clusters (Jeong and Chun, 2006). The agglomerates of clay and nanofibers, or the particles of quartz, K-feldspar, and plagioclase with clay and nanofiber coatings, were then blown to form Asian dust. Thus, calcite nanofibers associated with giant particles (Figs. 4, 5a) are the nanoscopic features of Asian dust particles blown from remote arid sources. However, secondary calcite is absent from the aeolian deposits of Korea (Jeong et al., 2013). This suggests a complete 
leaching of calcite in the acidic soils of Korea under humid climate conditions compared with the calcareous arid soils in the Asian dust sources. Thus, the common presence of calcite nanofibers associated with giant dust particles (Fig. 4) provides the direct evidence of their long-range transport.

The mineral particles collected on the central North Pacific, north of Hawaii, by Betzer et al. (1988) were exceptionally large $(>75 \mu \mathrm{m})$, and can be called ultragiant particles. They suggested that the particles were transported over $10,000 \mathrm{~km}$ from Asian sources using backward trajectory. However, the Asian desert origin of the ultragiant particles is required to be further confirmed by observing the nanoscopic features such as nanofiber calcite.

Díaz-Hernández and Párraga (2008) reported pinkish mineral microspherulites referred to as iberulites deposited on the southern Iberian Peninsula. The microspherulites are giant particles with a common size range of $60-80 \mu \mathrm{m}$. They were formed by the evaporation of cloud water droplets that collided with Saharan dust particles. Thus, the cloud processing is a possible mechanism of the formation of giant dust particles. However, iberulite is characterized by high sphericity, high porosity (a bulk density of $0.65 \mathrm{~g} \mathrm{~cm}^{-3}$ ), vortex depression, and coarse internal agglomeration grading to fine, thin clay rinds. The irregular giant particles in this study lack the microscopic features of iberulite. They were not the results of cloud processing, but directly transported from the Gobi Desert sources.

\subsection{Synoptic conditions of Asian dust laden with giant particles}

Since it was revealed that the extraordinary high fraction of giant particles in 2012 Asian dust was the result of longrange transport from the source region rather than local origin, we investigated the synoptic meteorological conditions compared with 2011 and 2010 dust events.

Aerosol index images from the COMS satellite revealed that the outbreak regions, migration routes, and transport distances of the three dusts were almost identical: the Gobi Desert of southern Mongolia and northern China $\left(40^{\circ}-46^{\circ} \mathrm{N}\right.$, $90^{\circ}-110^{\circ} \mathrm{E}$ ) (Fig. 1). However, the flight time of the 2012 dust was relatively short ( $28 \mathrm{~h}$ ) while those of 2011 and 2010 dusts were 45 and $35 \mathrm{~h}$, respectively.

Asian dust incursions in Korea are closely associated with synoptic conditions over dust source regions 2-3 days earlier (Chun et al., 2001; Kim et al., 2010). For example, Chun et al. (2001) showed that a strong pressure gradient with strong baroclinic instability at $850 \mathrm{hPa}$ (about $1.5 \mathrm{~km}$ level) over the dust source region is associated with outbreaks of Asian dust in spring. Such strong pressure gradients behind the developing low-pressure system result in high surface wind speeds, which are necessary for dust uplift (Husar et al., 2001). In addition, the strong wind belt in the mid-troposphere is closely related to dust migration. Thus, the dust arrival is much faster if the strong wind belt at $500 \mathrm{hPa}$ (about $5 \mathrm{~km}$ ) stretches directly to Korea (Chun et al., 2001).

To examine the synoptic conditions related to the outbreak and migration of dust, we used daily mean of the geopotential height and temperature at $850 \mathrm{hPa}$, wind speed at $500 \mathrm{hPa}$, and $10 \mathrm{~m}$ wind speed (as a proxy for the surface wind conditions) derived from the European Centre for Medium-Range Weather Forecasts Reanalysis Interim (ERA-Interim) data. We also used the ultraviolet (UV) aerosol index obtained from the Ozone Monitoring Instrument (OMI) onboard the EOS Aura satellite to identify the intensity and locations of the dust. The OMI UV-aerosol index provides qualitative information on the presence of UV-absorbing aerosols such as desert dust or smoke, without interference by ice, snow, and clouds (Ahn et al., 2008).

The 2012 dust event showed unusual characteristics. The intensity of dust at the source region was much weaker, but the transport was much faster than the previous events, even though the dust source regions in the Gobi Desert were almost identical. The meteorological characteristics of the 2012, 2011, and 2010 dust events are shown in Fig. 7. During both the 2010 and 2011 dust events, strong pressure gradients associated with strong baroclinic instability at $850 \mathrm{hPa}$ were observed over the Gobi Desert on 19 March 2010, and 29 April 2011 (Fig. 7). The strong pressure gradients resulted in a high surface wind speed $\left(>12 \mathrm{~m} \mathrm{~s}^{-1}\right)$ over the dust source region and thus induced severe dust storms. The dust-laden air mass followed the eastward-moving low-pressure systems and took about 1.5-2 days to reach Korea on both occasions. Despite the similar mechanisms of dust generation and transport in both events, the transport speed was slower, and the duration for which the dust persisted was longer during the 2011 event than the 2010 event because of the lower wind speed at $500 \mathrm{hPa}$ and stagnant atmospheric conditions associated with a high-pressure system over China. This is consistent with the number and volume proportions of giant particles slightly higher in the 2010 event.

During the 2012 dust event, a strong pressure gradient over the Gobi Desert appeared ahead of an expanding high-pressure system over central China on 30 March 2012 (Fig. 7). However, the strong pressure gradient was relatively weak compared with typical dust events. The weak baroclinicity on the boundary of the anticyclone induced a relatively low surface wind speed $\left(\sim 8 \mathrm{~m} \mathrm{~s}^{-1}\right)$ over the dust source region and hence resulted in a weak dust event. The synoptic conditions during the 2012 event were similar to the typical winter synoptic conditions produced by anticyclones over the continent and cyclones in the east. Between the high and low pressure systems, the contour lines of the $850 \mathrm{hPa}$ geopotential height and $500 \mathrm{hPa}$ strong wind belt were stretched directly southeastward from the Gobi Desert to Korea. These peculiar meteorological characteristics ensured much faster migration of dust and resulted in the extraordinary delivery of abundant giant particles to Korea during the 2012 dust event, even though the dust intensity was relatively weak. 


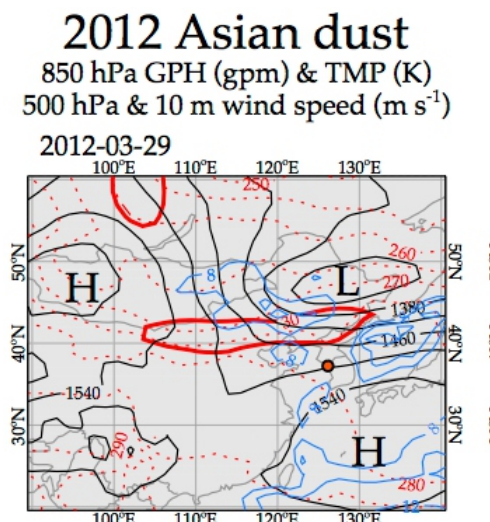

\section{Asian dust \\ $850 \mathrm{hPa}$ GPH (gpm) \& TMP (K)}

$500 \mathrm{hPa} \& 10 \mathrm{~m}$ wind speed $\left(\mathrm{m} \mathrm{s}^{-1}\right)$ 2011-04-29
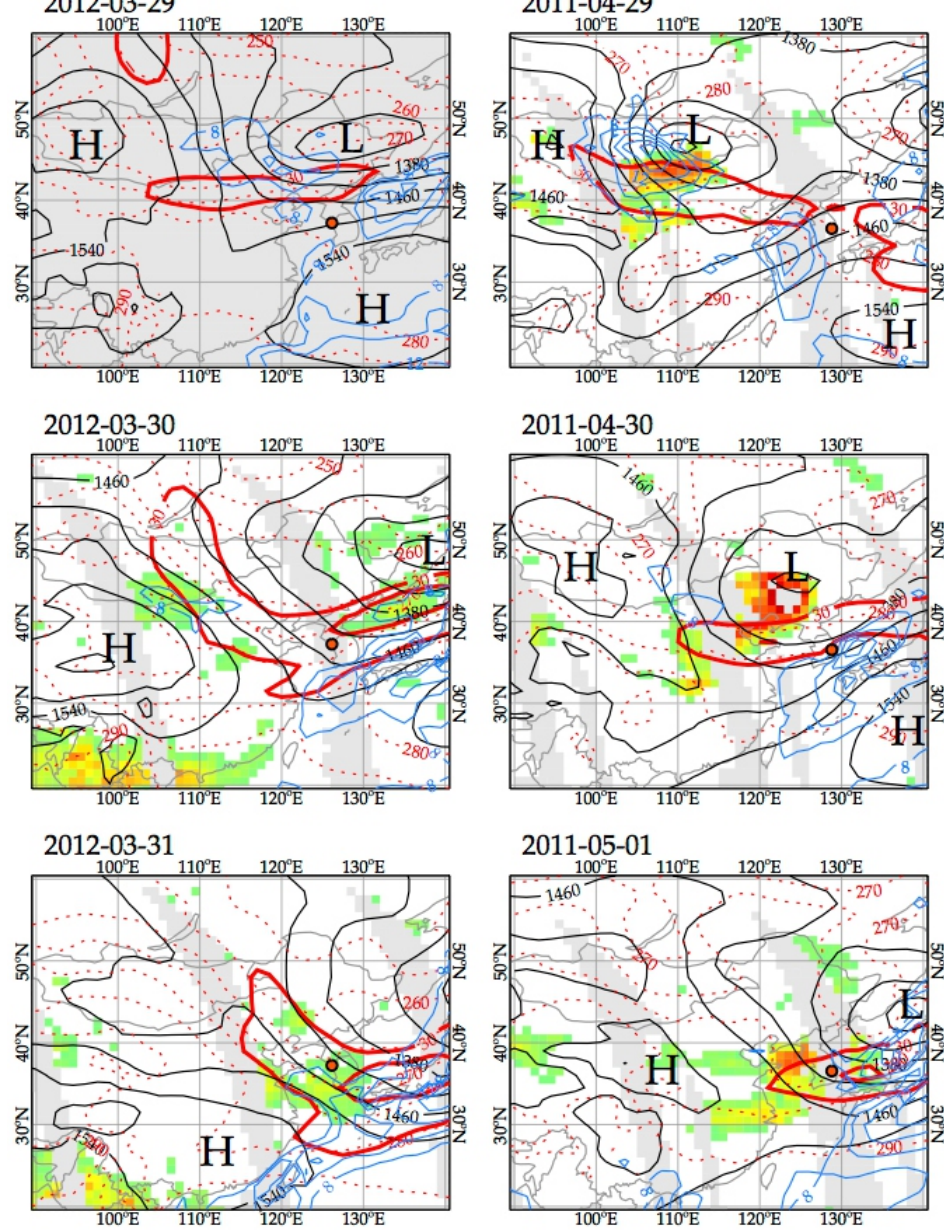

\section{Asian dust}

$850 \mathrm{hPa}$ GPH (gpm) \& TMP (K)

$500 \mathrm{hPa} \& 10 \mathrm{~m}$ wind speed $\left(\mathrm{m} \mathrm{s}^{-1}\right)$

2010-03-19
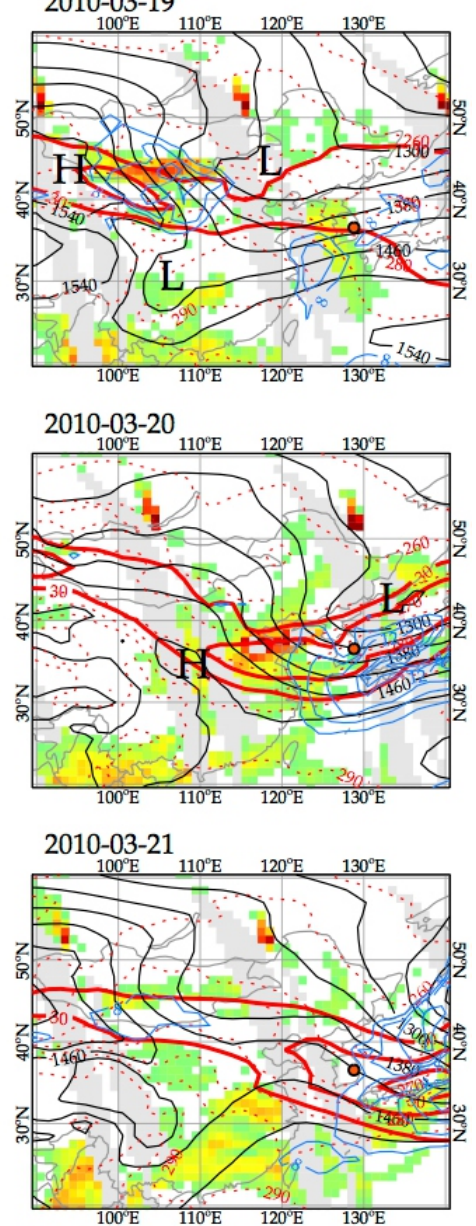

\begin{tabular}{lllllllllllll|lllllllllllllll}
\hline 15 & 20 & 25 & 30 & 35 & 40 & 45 & 50 & 55 & 60 & 65 & 70 & 75 & 80 & 85 & 90 & 95 & 100 & 105 & 110 & 115 & 120 & 125 & 130 & 135
\end{tabular} Aura-OMI aerosol index

Fig. 7. Daily evolution of the 2010, 2011, and 2012 dust events with ERA-Interim daily meteorological fields superimposed on an Aura-OMI aerosol index over East Asia. Black solid lines and red dotted lines represent the $850 \mathrm{hPa}$ geopotential height (gpm) and temperature (K). Blue thin solid lines and red thick solid lines indicate $10 \mathrm{~m}$ wind speed above $8 \mathrm{~m} \mathrm{~s}^{-1}$ and $500 \mathrm{hPa}$ wind speed above $30 \mathrm{~m} \mathrm{~s}^{-1}$, respectively. The solid orange circles are the TSP sampling sites. Missing values of the OMI aerosol index are shown in light gray color.

The mechanism of the long-range transport of giant particles of several tens of micrometers over several thousands of kilometers is unclear so far (Betzer et al., 1988; Goudie and Middleton, 2001). Giant particles could be transported over long distances when strong upward advection of air masses lifts dust particles to higher altitudes (Windom, 1985; Pye, 1995). Betzer et al. (1988) suggested a resuspension mechanism in the isolated storm along the particles' path. In the 2012 dust event, the dust outbreak and migration are accompanied by a locally strong updraft of $0.09 \mathrm{~m} \mathrm{~s}^{-1}$ at $700 \mathrm{hPa}$ (about $3 \mathrm{~km}$ level) until its arrival over the Yellow Sea (figure not shown). If we assumed a sand-like irregu- lar shaped giant particle with a diameter of $50 \mu \mathrm{m}$ and density of $2.3 \mathrm{~g} \mathrm{~cm}^{-3}$, its settling velocity reaches approximately $0.11 \mathrm{~m} \mathrm{~s}^{-1}$ or $9.5 \mathrm{~km} \mathrm{day}^{-1}$ (Reid et al., 2003). However, the local updraft can significantly reduce the settling velocity, and this mechanism with the fast migration of the 2012 dust event is physically consistent with the transport of the giant particles over the long distance of $2000 \mathrm{~km}$. 


\subsection{Ancient records of giant Asian dust particles in Korea}

The enormous volume of giant particles suggests that deposition of Asian dust would occur near the dust source like in the Chinese Loess Plateau. However, they also contributed to the formation of an aeolian sedimentary body in remote environments.

The particle size and morphology of quartz and feldspars in ancient aeolian sediments (Fig. 2d) in the Paleolithic excavation sites of Korea (Shin et al., 2004; Jeong et al., 2013) are markedly similar to the 2012 dust (Fig. 2a). The origin of the fine clays forming the matrix enclosing quartz and feldspar particles is unknown. However, the common occurrence of giant clay agglomerates in the 2012 dust (Table 2 and Fig. 4d, e) suggests that even the fine clays in the sediments (Fig. 2d) were also derived from giant clay agglomerates. The original morphology and size of clay agglomerates in Asian dust may have been altered by post-depositional pedogenic activity. Thus, the long-term deposition of giant particles through the late Quaternary likely represents major terrestrial input of minerals from long-range transported dust to form an aeolian sedimentary body in East Asia.

The giant particles of ancient Asian dust contributed to the far and remote sedimentary body out of the Asian region. Betzer et al. (1988) suggested the recent anthropogenic disturbance as the cause of the giant dust particles delivered to the North Pacific because giant particles are rare in the deepsea sediment core of the North Pacific. However, Beget et al. (1993) reported quartz particles as large as 40-60 $\mu \mathrm{m}$ in the late Quaternary tephric loess deposits on the island of Hawaii. There is evidence supporting the long-range transport of large particles, as summarized in Goudie and Middleton (2001), e.g., quartz grains of up to $90 \mu \mathrm{m}$ in diameter on Sal Island (Cape Verde Islands) off West Africa (Glaccum and Prospero, 1980) and particles $>20 \mu \mathrm{m}$ in diameter transported $4000 \mathrm{~km}$ from their Saharan source (Prospero et al., 1970). Thus, mass contribution of giant particles to the terrestrial and ocean sediments may have been higher than previously thought at least on a regional scale.

\subsection{Transport of reactive minerals and nutrients}

Iron dissolved from dust particles is important in Fe-deficient marine ecosystems of high-nutrient, low-chlorophyll regions, such as the eastern subarctic North Pacific and the Southern Ocean (Boyd et al., 2004). Fine clay minerals and nanofiber calcite with a large surface area and cation exchange capacity are sensitive minerals that react with acidic gases/droplets and organic/inorganic pollutants. The major form of clay minerals and nano-sized calcites transported are giant clay agglomerates, as revealed by SEM analyses, which showed that giant particles accounted for $89 \%$ of the total volume of the 2012 dust. Mineral dusts supply inorganic nutrients to remote sea locations. The settling rates of giant particles are higher than fine particles. Important inorganic nutrients (e.g., $\mathrm{Fe}$ ) are associated with fine particles such as Fe-bearing clay minerals and iron oxides. TEM imaging and EDX spectroscopy of individual clay grains of the Asian dusts and their deposits (Chinese loess) showed that ISCMs contain ca. 5$7 \%$ of Fe (Jeong, 2008; Jeong et al., 2008, 2011; this study). About $85 \%$ (vol.) of ISCMs are included in the giant agglomerate particles (Table 3, Fig. 4d, e). Large clay agglomerates are a major source of inorganic nutrients in some regions of the ocean, in comparison to fine particles with a slow settling velocity and long residence time.

\section{Summary and conclusions}

Particle size, mineralogy, and meteorological characteristics of the Asian dust event on 31 March 2012, were investigated and compared with two previous events in 2010 and 2011. The median equivalent sphere diameters from the number size distributions were 5.7, 2.9, and $2.5 \mu \mathrm{m}$ in the 2012, 2011, and 2010 dust events, respectively, and were consistent with independent OPC data. Twenty percent of the particles in the 2012 dust event were giant (giant-S and giant-L) particles, with a maximum size of $60 \mu \mathrm{m}$. They contributed $89 \%$ of the total dust volume in the 2012 dust and were either agglomerates of submicron clay minerals, or large quartz and feldspar grains with clay-mineral coatings. The occurrence of calcite nanofibers associated with giant particles confirmed their long-range transport from remote arid sources. Illite-smectite series clay minerals were the major mineral group followed by quartz, plagioclase, K-feldspar, and calcite. Mineral compositions showed little variation through the fine, coarse, giant-S, and giant-L size bins because the fine clay minerals formed larger agglomerates. Mineral compositions varied little through the three dust events, but fine clay minerals were more common in the 2010 and 2011 dusts. The particle-size characteristics of the mineral dust may be dependent on the synoptic conditions of the dust outbreak and migration. During the 2012 Asian dust event, a mid-tropospheric strong wind belt stretched southeastward from the Gobi Desert to Korea, making the rapid migration of dust possible, and delivering abundant giant particles. Atmospheric aerosol studies usually focus on particles $<10 \mu \mathrm{m}$. However, the role of giant particles should be reviewed with regard to the regional circulation of earth materials through the lithosphere, pedosphere, and atmosphere. For example, analysis of ancient aeolian deposits in Korea suggested the common deposition of giant particles from Asian dust through the Quaternary Period. 
Acknowledgements. This work was supported by the National Research Foundation of Korea grant NRF-2011-0028597. We thank Mihály Posfai and three anonymous referees for their thoughtful comments.

Edited by: X. Querol

\section{References}

Ackerman, S. A.: Remote sensing aerosols using satellite infrared observations, J. Geophys. Res.-Atmos., 102, 1706917079, 1997.

Ahn, C., Torres, O., and Bhartia, P. K.: Comparison of ozone monitoring instrument UV aerosol products with aqua/moderate resolution imaging spectroradiometer and multiangle imaging spectroradiometer observations in 2006, J. Geophys. Res.-Atmos., 113, D16S27, doi:10.1029/2007JD008832, 2008.

Arimoto, R., Ray, B. J., Lewis, N. F., and Tomza, U.: Mass-particle size distributions of atmospheric dust and the dry deposition of dust to the remote ocean, J. Geophys. Res.-Atmos., 102, 1586715874, 1997.

Beget, J. E., Keskinen, M., and Severin, K.: Mineral particles from Asia found in volcanic loess on the island of Hawaii, Sediment. Geol., 84, 189-197, 1993.

Betzer, P. R., Carder, K. L., Duce, R. A., Merrill, J. T., Tindale, N. W., Uematsu, M., Costello, D. K., Young, R. W., Feely, R. A., Breland, J. A., Bernstein, R. E., and Greco, A. M.: Long-range transport of giant mineral aerosol particles, Nature, 336, 568$571,1988$.

Blanco, A., De Tomasi, F., Filippo, E., Manno, D., Perrone, M. R., Serra, A., Tafuro, A. M., and Tepore, A.: Characterization of African dust over southern Italy, Atmos. Chem. Phys., 3, 21472159, doi:10.5194/acp-3-2147-2003, 2003.

Boyd, P. W., Law, C. S., Wong, C. S., Nojiri, Y., Tsuda, A., Levasseur, M., Takeda, S., Rivkin, R., Harrison, P. J., Strzepek, R., Gower, J., McKay, R. M., Abraham, E., Arychuk, M., BarwellClarke, J., Crawford, W., Hale, M., Harada, K., Johnson, K., Kiyosawa, H., Kudo, I., Marchetti, A., Miller, W., Needoba, J., Nishioka, J., Ogawa, H., Page, J., Robert, M., Saito, H., Sastri, A., Sherry, N., Soutar, T., Sutherland, N., Taira, Y., Whitney, F., Wong, S. -K. E., and Yoshimura, T.: The decline and fate of an iron-induced subarctic phytoplankton bloom, Nature, 428, 549553, doi:10.1038/nature02437, 2004.

Bradley, R. S.: Paleoclimatology: Reconstructing Climates of the Quaternary, Academic Press, 1999.

Brady, N. C.: The Nature and Properties of Soils, Macmillan Publishing Company, New York, 1990.

Chaboureau, J. -P., Tulet, P., and Mari, C.: Diurnal cycle of dust and cirrus over West Africa as seen from Meteosat Second Generation satellite and a regional forecast model, Geophys. Res. Lett., 34, L02822, doi:10.1029/2006GL027771, 2007.

Chun, Y., Boo, K.-O., Kim, J., Park, S. -U., and Lee, M.: Synopsis, transport, and physical characteristics of Asian dust in Korea, J. Geophys. Res.-Atmos., 106, 18461-18469, 2001.

Chun, Y., Lim, J.-Y., and Choi, B. -C.: The features of aerosol in Seoul by Asian dust and haze during springtime from 1998 to 2002, J. Korean Meteorol. Soc., 39, 459-474, 2003.

Coude-Gaussen, G., Rognon, P., Bergametti, G., Gomes, L., Strauss, B., Gros, J. M., and Le Coustumer, M. N.: Saharan dust on Fuerteventura Island (Canaries): Chemical and mineralogical characteristics, air mass trajectories, and probable sources, J. Geophys. Res.-Atmos., 92, 9753-9771, 1987.

Dentener, F. J., Carmichael, G. R., Zhang, Y., Lelieveld, J., and Crutzen, P. J.: Role of mineral aerosol as a reactive surface in the global troposphere, J. Geophys. Res.-Atmos., 101, 2286922889, 1996.

Díaz-Hernández, J. L., and Párraga, J.: The nature and tropospheric formation of iberulites: Pinkish mineral microspherulites, Geochim. Cosmochim. Acta, 72, 3883-3906, 2008.

Dockery, D. W., Pope, C. A., Xu, X., Spengler, J. D., Ware, J. H., Fay, M. E., Ferris Jr., B. G., and Speizer, F. E.: An association between air pollution and mortality in six US cities, New Engl. J. Med., 329, 1753-1759, 1993.

Fletcher, R. A., Ritchie, N. W. M., Anderson, I. M., and Small, J. A.: Microscopy and microanalysis of individual collected particles, in: Aerosol Measurement, edited by: Kulkarni, P., Baron, P. A., and Willeke, K., Wiley, printed in the USA, 179-232, 2011.

Ginoux, P.: Effects of nonsphericity on mineral dust modeling, J. Geophys. Res.-Atmos., 108, 4052, doi:10.1029/2002JD002516, 2003.

Glaccum, R. A. and Prospero, J. M.: Saharan aerosols over the tropical north Atlantic - Mineralogy, Mar. Geol., 37, 295-321, 1980.

Goudie, A. S. and Middleton, N. J.: Saharan dust storms: nature and consequences. Earth Sci. Rev., 56, 179-204, 2001.

Hong, S. J., Kim, J. H., and Ha, J. S.: Possibility of applying infrared background threshold values for detecting Asian dust in spring from geostationary satellite, Korean J. Remote Sens., 26, 387394 (in Korean), 2010.

Husar, R. B., Tratt, D. M., Schichtel, B. A., Falke, S. R., Li, F., Jaffe, D., Gassó, S., Gill, T., Laulainen, N. S., Lu, F., Reheis, M. C., Chun, Y., Westphal, D., Holben, B. N., Gueymard, C., McKendry, I., Kuring, N., Feldman, G. C., McClain, C., Frouin, R. J., Merrill, J., DuBois, D., Vignola, F., Murayama, T., Nickovic, S., Wilson, W. E., Sassen, K., Sugimoto, N., and Malm, W. C.: Asian dust events of April 1998, J. Geophys. Res.-Atmos., 106, 18317-18330, 2001.

In, H. -J. and Park, S. -U.: A simulation of long-range transport of Yellow Sand observed in April 1998 in Korea, Atmos. Environ., 36, 4173-4187, 2002.

Jeong, G. Y.: Bulk and single-particle mineralogy of Asian dust and a comparison with its source soils, J. Geophys. Res.-Atmos., 113, D02208, doi:10.1029/2007JD008606, 2008.

Jeong, G. Y. and Chun, Y.: Nanofiber calcite in Asian dust and its atmospheric roles, Geophys. Res. Lett., 33, L24802, doi:10.1029/2006GL028280, 2006.

Jeong, G. Y. and Lee, K. -S: A mineral tracer toward high-resolution dust provenance on the Chinese Loess Plateau: SEM, TEM, and sulfur isotopes of sulfate inclusions in biotite, Am. Mineral., 95, 64-72, 2010.

Jeong, G. Y., Hillier, S., and Kemp, R. A.: Quantitative bulk and single-particle mineralogy of a thick Chinese loess-paleosol section: implications for loess provenance and weathering, Quaternary Sci. Rev., 37, 1271-1287, 2008.

Jeong, G. Y., Hillier, S., and Kemp, R. A.: Changes in mineralogy of loess-paleosol sections across the Chinese Loess Plateau, Quat. Res., 75, 245-255, 2011. 
Jeong, G. Y., Choi, J. -H., Lim, H. S., Seong, C., and Yi, S. B.: Deposition and weathering of Asian dust in Paleolithic sites, Korea, Quat. Sci. Rev., 78, 283-300, 2013.

Kanayama, S., Yabuki, S., Yanagisawa, F., and Motoyama, R.: The chemical and strontium isotope composition of atmospheric aerosols over Japan: the contribution of long-range-transported Asian dust (Kosa), Atmos. Environ., 36, 5159-5175, 2002.

Kandler, K., Benker, N., Bundke, U., Cuevas, E., Ebert, M., Knippertz, P., Rodríguez, S., Schütz, L., and Weinbruch, S.: Chemical composition and complex refractive index of Saharan Mineral Dust at Izaña, Tenerife (Spain) derived by electron microscopy, Atmos. Environ., 41, 8058-8074, 2007.

Kim, S.-W., Yoon, S.-C., and Kim, J.: Columnar Asian dust particle properties observed by sun/sky radiometers from 2000 to 2006 in Korea. Atmos. Environ., 42, 492-504, 2008.

Kim, S.-W., Yoon, S. -C., Kim, J., Kang, J.-Y., and Sugimoto, N.: Asian dust event observed in Seoul, Korea, during 29-31 May 2008: Analysis of transport and vertical distribution of dust particles from lidar and surface measurements, Sci. Total Environ., 408, 1707-1718, 2010.

Korea Meteorological Administration (KMA): http://web.kma.go. kr/eng/weather/asiandust/timeseries.jsp (last access: 7 November 2013), 2013.

Laskin, A., Wietsma, T. W., Krueger, B. J., and Grassian, V. H.: Heterogeneous Chemistry of Individual Mineral Dust Particles with Nitric Acid: A Combined CCSEM/EDX, ESEM, and ICP-MS Study, J. Geophys. Res.-Atmos., 110, D10208, doi:10.1029/2004JD005206, 2005.

Legrand, M., Plana-Fattori, A., and N'doumé, C.: Satellite detection of dust using the IR imagery of Meteosat: 1. Infrared difference dust index, J. Geophys. Res.-Atmos., 106, 18251-18274, 2001.

McKendry, I. G., Macdonald, A. M., Leaitch, W. R., van Donkelaar, A., Zhang, Q., Duck, T., and Martin, R. V.: Trans-Pacific dust events observed at Whistler, British Columbia during INTEXB, Atmos. Chem. Phys., 8, 6297-6307, doi:10.5194/acp-8-62972008, 2008.

Meskhidze, N., Chameides, W. L., and Nenes, A.: Dust and pollution: a recipe for enhanced ocean fertilization, J. Geophys. Res.Atmos., 110, D03301, doi:10.1029/2004JD005082, 2005.

Mikami, M., Shi, G.Y., Uno, I., Yabuki, S., Iwasaka, Y., Yasui, M., Aoki, T., Tanaka, T.Y., Kurosaki, Y., Masuda, K., Uchiyama, A., Matsuki, A., Sakai, T., Takemi, T., Nakawo, M., Seino, N., Ishizuka, M., Satake, S., Fujita, K., Hara, Y., Kai, K., Kanayama, S., Hayashi, M., Du, M., Kanai, Y., Yamada, Y., Zhang, X. Y., Shen, Z., Zhou, H., Abe, O., Nagai, T., Tsutsumi, Y., Chiba, M., and Suzuki, J.: Aeolian dust experiment on climate impact: An overview of Japan-China joint project ADEC, Global Planet. Change, 52, 142-172, 2006.

Mori, I., Nishikawa, M., Tanimura, T., and Quan, H.: Change in size distribution and chemical composition of kosa (Asian dust) aerosol during long-range transport, Atmos. Environ., 37, 42534263, 2003.

National Meteorological Satellite Center: http://nmsc.kma.go.kr/ html/homepage/en/main.do (last access: 7 November 2013), 2013.

Park, S.-U. and Kim, J. -W.: Aerosol size distributions observed at the Seoul National University campus in Korea during the Asian dust and non-Asian dust periods, Atmos. Environ., 40, 17221730,2006
Park, S.-U., Chang, L.-S., and Lee, E.-H.: Direct radiative forcing due to aerosols in East Asia during a Hwangsa (Asian dust) event observed on 19-23 March 2002 in Korea, Atmos. Environ., 39, 2593-2606, 2005.

Prospero, J. M., Bonatti, E., Schuber, C., and Carlson, T. N.: Dust in the Caribbean traced to an African dust storm, Earth Planet. Sci. Lett., 9, 287-293, 1970.

Pye, K.: The nature, origin and accumulation of loess, Quaternary Sci. Rev., 14, 653-667, 1995.

Reid, J. S., Jonsson, H. H., Maring, H. B., Smirnov, A., Savoie, D. L., Cliff, S. S., Reid, E. A., Livingston, J. M., Meier, M. M., Dubovik, O., and Tsay, S. C.: Comparison of size and morphological measurements of coarse mode dust particles from Africa J. Geophys. Res., 108, doi:10.1029/2002JD002485, 2003.

Reist, P. C.: Aerosol Science and Technology, McGraw-Hill, New York, 1993.

Seinfeld, J. H. and Pandis, S. N.: Atmospheric Chemistry and Physics, John Wiley, Hoboken, NJ, 2006.

Seinfeld, J. H., Carmichael, G. R., Arimoto, R., Conant, W. C., Brechtel, F. J., Bates, T. S., Cahill, T. A., Clarke, A. D., Doherty, S. J., Flatau, P. J., Huebert, B. J., Kim, J., Markowicz, K. M., Quinn, P. K., Russell, L. M., Russell, P. B., Shimizu, A., Shinozuka, Y., Song, C. H., Tang, Y., Uno, I., Vogelmann, A. M., Weber, R. J., Woo, J. -H, and ZhanG, X. Y.: ACE-ASIA regional climatic and atmospheric chemical effects of Asian dust and pollution, B. Am. Meteorol. Soc., 85, 367-380, 2004.

Shi, Z., Shao, L., Jones, T. P., and Lu, S.: Microscopy and mineralogy of airborne particles collected during severe dust storm episodes in Beijing, China, J. Geophys. Res., 110, D01303, doi:10.1029/2004JD005073, 2005.

Shin, J.-B., Yu, K.-M., Naruse, T., and Hayashida, A.: Study on loess-paleosol stratigraphy of Quaternary unconsolidated sediments at E55S20-IV pit of Chongokni Paleolithic site, Journal of the Geological Society of Korea, 41, 369-381 (in Korean with English abstract), 2004.

Song, Y.-C., Eom, H. -J., Jung, H.-J., Malek, M. A., Kim, H. K., Geng, H., and Ro, C.-U.: Investigation of aged Asian dust particles by the combined use of quantitative ED-EPMA and ATR-FTIR imaging. Atmos. Chem. Phys., 13, 3463-3480, doi:10.5194/acp-13-3463-2013, 2013.

Sullivan, R. C., Moore, M. J. K., Petters, M. D., Kreidenweis, S. M., Roberts, G. C., and Prather, K. A.: Effect of chemical mixing state on the hygroscopicity and cloud nucleation properties of calcium mineral dust particles, Atmos. Chem. Phys., 9, $3303-$ 3316, doi:10.5194/acp-9-3303-2009, 2009.

Tegen, I., and Lacis, A. A.: Modeling of particle size distribution and its influence on the radiative properties of mineral dust aerosol, J. Geophys. Res., 101, 19237-19244, 1996.

Weaver, C. E.: Clays, Muds, and Shales, Elsevier, Amsterdam, The Netherlands, 1989.

Westphal, D. L., Toon, O. B., and Carlson, T. N.: A two-dimensional numerical investigation of the dynamics and microphysics of Saharan dust storms, J. Geophys. Res., 92, 3027- 3049, 1987.

Windom, H. L.: Eolian contributions to marine sediments. J. Sediment. Petrol., 45, 520-529, 1985. 